\title{
Continental hydrosystem modelling: the concept of nested stream-aquifer interfaces
}

\author{
N. Flipo ${ }^{1}$, A. Mouhri ${ }^{1,2,3}$, B. Labarthe ${ }^{1}$, S. Biancamaria ${ }^{4}$, A. Rivière ${ }^{1}$, and P. Weill ${ }^{1}$ \\ ${ }^{1}$ MINES ParisTech, PSL Research University, Geosciences Department, Paris, France \\ ${ }^{2}$ Sorbonne Universités, UPMC Univ Paris 06, UMR7619 - METIS, Paris, France \\ ${ }^{3}$ CNRS, UMR7619 - METIS, Paris, France \\ ${ }^{4}$ CNRS, LEGOS, UMR5566 - CNRS-CNES-IRD-Université Toulouse III, Toulouse, France \\ Correspondence to: N. Flipo (nicolas.flipo@mines-paristech.fr)
}

Received: 16 December 2013 - Published in Hydrol. Earth Syst. Sci. Discuss.: 14 January 2014

Revised: 28 June 2014 - Accepted: 1 July 2014 - Published: 21 August 2014

\begin{abstract}
Coupled hydrological-hydrogeological models, emphasising the importance of the stream-aquifer interface, are more and more used in hydrological sciences for pluridisciplinary studies aiming at investigating environmental issues. Based on an extensive literature review, stream-aquifer interfaces are described at five different scales: local $[10 \mathrm{~cm}-$ $\sim 10 \mathrm{~m}]$, intermediate $[\sim 10 \mathrm{~m}-\sim 1 \mathrm{~km}]$, watershed $\left[10 \mathrm{~km}^{2}-\right.$ $\sim 1000 \mathrm{~km}^{2}$ ], regional $\left[10000 \mathrm{~km}^{2} \sim \sim 1 \mathrm{M} \mathrm{km}^{2}\right]$ and continental scales $\left[>10 \mathrm{M} \mathrm{km}^{2}\right]$. This led us to develop the concept of nested stream-aquifer interfaces, which extends the well-known vision of nested groundwater pathways towards the surface, where the mixing of low frequency processes and high frequency processes coupled with the complexity of geomorphological features and heterogeneities creates hydrological spiralling. This conceptual framework allows the identification of a hierarchical order of the multi-scale control factors of stream-aquifer hydrological exchanges, from the larger scale to the finer scale. The hyporheic corridor, which couples the river to its 3-D hyporheic zone, is then identified as the key component for scaling hydrological processes occurring at the interface. The identification of the hyporheic corridor as the support of the hydrological processes scaling is an important step for the development of regional studies, which is one of the main concerns for water practitioners and resources managers.

In a second part, the modelling of the stream-aquifer interface at various scales is investigated with the help of the conductance model. Although the usage of the temperature as a tracer of the flow is a robust method for the assessment of stream-aquifer exchanges at the local scale, there
\end{abstract}

is a crucial need to develop innovative methodologies for assessing stream-aquifer exchanges at the regional scale. After formulating the conductance model at the regional and intermediate scales, we address this challenging issue with the development of an iterative modelling methodology, which ensures the consistency of stream-aquifer exchanges between the intermediate and regional scales.

Finally, practical recommendations are provided for the study of the interface using the innovative methodology MIM (Measurements-Interpolation-Modelling), which is graphically developed, scaling in space the three pools of methods needed to fully understand stream-aquifer interfaces at various scales. In the MIM space, stream-aquifer interfaces that can be studied by a given approach are localised. The efficiency of the method is demonstrated with two examples. The first one proposes an upscaling framework, structured around river reaches of $\sim 10-100 \mathrm{~m}$, from the local to the watershed scale. The second example highlights the usefulness of space borne data to improve the assessment of streamaquifer exchanges at the regional and continental scales. We conclude that further developments in modelling and field measurements have to be undertaken at the regional scale to enable a proper modelling of stream-aquifer exchanges from the local to the continental scale. 


\section{Introduction}

The emergence of a systemic view of the hydrological cycle led to the concept of continental hydrosystem (Dooge, 1968; Kurtulus et al., 2011), which "is composed of storage components where water flows slowly (e.g. aquifers) and conductive components, where large quantities of water flow relatively quickly (e.g. surface water)" (Flipo et al., 2012, p. 1). This concept merges surface and ground waters into the same hydrological system through the stream-aquifer interface. Recently, Fan et al. (2013) estimated that 22-32\% of the land surface is influenced by shallow groundwater. As a key transitional component characterised by a high spatiotemporal variability in terms of physical and biogeochemical processes (Brunke and Gonser, 1997; Krause et al., 2009b), this interface requires further consideration for characterising the hydrogeological behaviour of basins (Hayashi and Rosenberry, 2002), and therefore continental hydrosystem functioning (Saleh et al., 2011).

Water exchange dynamics at the stream-aquifer interface are complex and mainly depend on geomorphological, hydrogeological, and climatological factors (Sophocleous, 2002; Winter, 1998). Recent ecohydrological publications, dedicated to stream-aquifer interfaces, claim the recognition of the complexity of the multi-scale processes taking place at the interface (Ellis et al., 2007; Hancock et al., 2005; Poole et al., 2008; Stonedahl et al., 2012).

A number of published papers address the problem of reactive transport through the stream-aquifer interface. These papers imply sophisticated models, which represent the dynamics of pollutants at the local scale (Bardini et al., 2012; Chen and MacQuarrie, 2004; Doussan et al., 1997; Gu et al., 2008; Marzadri et al., 2011; Peyrard et al., 2011) fairly well, taking into account the effect of local heterogeneities, microtopography and of sharp redox gradients on the exchanged fluxes. These models are used to investigate complex processes, such as the effect of micro-topography on flow paths and associated geochemical fluxes (Frei et al., 2012), or the potential effect of bank storage on denitrification ( $\mathrm{Gu}$ et al., 2012), as well as the effect on the stream curvature to hyporheic biogeochemical zonation (Boano et al., 2010b). At the regional scale, coupled rainfall-runoff hydrological models and biogeochemical models are able to simulate pollutant transport and removal such as nitrates (Billen and Garnier, 2000; Oeurng et al., 2010; Seitzinger et al., 2002; ThouvenotKorppoo et al., 2009). These models (i) underestimate the absolute water flux, flowing upwards and/or downwards, through the interface, and (ii) poorly simulate pollutants removal due to water fluxes through the sharp redox gradient of the hyporheic zone. This is due to their tautological nature, which does not integrate the proper physical processes, and also to their discretisation which does not account for subcell heterogeneities. Few applications considered the potential reversal of flow at the interface and its impact on nitrate removal at the catchment scale (Conan et al., 2003; Galbiati et al., 2006), but until today the exact quantification of the intensity of the removal due to various processes occurring at the stream-aquifer interface remains uncertain (Flipo et al., 2007a). Although certain control factors of biogeochemical processes occurring at the stream-aquifer interface are known, such as water residence time, nitrate concentration or organic matter content (Carleton and Montas, 2010; Dahm et al., 1998; Hill et al., 1998; Kjellin et al., 2007; Peyrard et al., 2011; Rivett et al., 2008; Weng et al., 2003), as well as water level fluctuations (Burt et al., 2002; Dahm et al., 1998; Hefting et al., 2004; Turlan et al., 2007), numerical models remain limited by their ability to simulate water pathways in the interface properly (Burt, 2005). Consequently, largescale biogeochemical models lack predictive abilities with regard to climate change issues or the assessment of the implementation of environmental regulatory frameworks, such as the European Water Framework Directive (WFD) (Parliament Council of the European Union, 2000).

Although the number of papers concerning stream-aquifer interfaces exponentially increased over the last 15 years (Fleckenstein et al., 2010), they mostly focus on local scale issues, following a classic bottom-up scientific approach (Nalbantis et al., 2011). The lack of models aiming at quantifying stream-aquifer exchanges at large basins' scale was already alleged by Fleckenstein et al. (2010) and Krause et al. (2011). The current review quantitatively confirms that the larger the scale (scale in the sense of model dimension), the less understood the interfaces. This is one of the major concerns for large-scale river basin managers. Indeed, they have difficulties to fulfill the requirements of, for instance, the European WFD, especially for providing guidelines towards a good ecological status of both surface water bodies and subsurface water bodies. State-of-the-art coupled surface-subsurface models nowadays fail to integrate ecohydrological concepts based on functionalities of morphological units (Bertrand et al., 2012; Dahl et al., 2007), mostly because they are not able yet to integrate the multi-scale nature of the stream-aquifer interfaces into a holistic view of the system.

Consequently, innovative methodologies for assessing stream-aquifer exchanges at the regional and continental scales need to be developed, which is a challenging issue for modellers (Fleckenstein et al., 2010; Graillot et al., 2014). The aim of this paper is to pave the way towards a multiscale modelling of the stream-aquifer interface, with the ambitious goal of being able to simulate the complexity of the processes occurring at the local scale in larger scale models, i.e. at the regional scale for large basin decision makers, and also at the continental scale, which is the primary scale of interest for the assessment of the effect of climate change on hydrosystems. In other words, this paper aims at rationalising the modelling of stream-aquifer interfaces within a consistent framework that fully accounts for the multi-scale nature of the stream-aquifer exchange processes (Marmonier 
et al., 2012). This is a necessary primary step before assessing hydrological impacts on geochemical fluxes.

Following the attempt of Mouhri et al. (2013), who rationalised the design of a stream-aquifer interface sampling system, we first define the various scales of interest. Based on a literature review, we include the hydrologic spiralling concept of Poole et al. (2008) - which denotes the complexity of water pathways in heterogeneous alluvial plains - into the nested groundwater pathways vision of Tóth (1963) to formulate the concept of nested stream-aquifer interfaces. This concept then allows us to identify stream-aquifer interfaces as a key transitional component of continental hydrosystems (Sect. 2). We also introduce a hierarchical order of the multi-scale controlling factors of stream-aquifer hydrological exchanges, from the larger scale to the finer scale. The stream network is finally identified as the key component for scaling hydrological processes occurring at the interface. In Sect. 3, the paper focuses on the streamaquifer interface modelling at various scales, with up-to-date methodologies. After describing the modelling approaches at the two extreme spatial scales, we emphasise which hydrological parameters and variables have to be up and downscaled around the river and also for which models. Finally, integrating the telescopic approach of Kikuchi et al. (2012) with the nested stream-aquifer interface concept, we develop the MIM (Measurements-Interpolation-Modelling) methodological framework for the design of multi-scale studies of stream-aquifer exchanges based on a more holistic view of the hydrosystem (Sect. 4). MIM is a valuable tool to define strategies for combining field measurements and modelling approaches more easily. Given the usage of the MIM methodology, we show that the scaling of processes from the local to the watershed scale is structured around river reaches of $\sim 10-100 \mathrm{~m}$. We also analyse the question of how to model stream-aquifer exchanges at the continental scale, and investigate the usage of remote sensing data, which should improve global hydrological budgets. We conclude that further developments in modelling and field measurements have to be performed at the regional scale to enable the proper modelling of stream-aquifer exchanges from the local to the continental scale.

\section{The concept of nested stream-aquifer interfaces}

\subsection{Historical developments of the nested stream-aquifer interface concept}

Stream-aquifer interfaces have only been intensively surveyed for two decades (Fleckenstein et al., 2006; Marmonier et al., 2012). Its study by the ecohydrological community led to a re-conceptualisation of its nature from the river being seen as an impervious drain that collects the effective rainfall and transfers it to the ocean, towards a more subtle view that integrates more spatio-temporal processes in the hydrosystem functioning. Indeed, the stream-aquifer interface is now conceptualised as a filter through which water flows many times over various spatial (from centimetres to kilometres) and temporal scales (from seconds to months) before reaching the sea (Datry et al., 2008). One of the main challenges is to understand the role of the streamaquifer interfaces in the hydro(geo)logical functioning of basins (Hayashi and Rosenberry, 2002). The multi-scale nature of the problem at hand imposes the definition of the scales of interest.

The five commonly recognised scales (in this context scale refers to the size of the studied objects) are the local, the reach, the catchment, the regional and the continental scales (Blöschl and Sivapalan, 1995; Dahl et al., 2007; Gleeson and Paszkowski, 2013), being defined as:

- Local scale (or the experimental site scale) $[10 \mathrm{~cm}-$ $\sim 10 \mathrm{~m}]$ : this scale concerns the riverbed or the hyporheic zone (HZ, see Sect. 2.2 for more details).

- Intermediate or reach scale $[\sim 10 \mathrm{~m}-\sim 1 \mathrm{~km}]$ : it concerns the river reach, a pond or a small lake.

- Catchment-watershed scale $\left[10 \mathrm{~km}^{2}-\sim 1000 \mathrm{~km}^{2}\right]$ or $[\sim 1 \mathrm{~km}-\sim 10 \mathrm{~km}]$ : this scale connects the stream network to its surface watershed and more broadly to the hydrosystem. This is the scale from which surfaceground water exchanges are linked to the hydrological cycle and the hydrogeological processes.

- Regional scale [10000 km²_ $\left.1 \mathrm{M} \mathrm{km}^{2}\right]$ or $[\sim 100 \mathrm{~km}-$ $\sim 1000 \mathrm{~km}]$ : this is the scale of water resources management, and the one for which the least is known about stream-aquifer exchange dynamics. For a conceptual analysis of the stream-aquifer interfaces, the watershed and the regional scales can be merged into a single category referred to as the regional scale (Mouhri et al., 2013). Merging these two scales is consistent with the fact that a regional basin is a collection of smaller watersheds. The distinction between the two categories is only necessary to conceptualise the scaling of processes as discussed in the final section of this paper.

- Continental scale $\left[>10 \mathrm{M} \mathrm{km}^{2}\right]$ or $[\sim 1000 \mathrm{~km}-$ $\sim 10000 \mathrm{~km}]:$ this scale is a collection of regional scale basins. The difference with the regional scale is that there is a broader range of hydro-climatic conditions, which imposes accounting for climatic circulations.

From a conceptual point of view, stream-aquifer exchanges are driven by two main factors: the hydraulic gradient and the geological structure. The hydraulic gradient defines the water pathways (Winter, 1998), whereas the geological structure defines the conductive properties of the streamaquifer interface (White, 1993; Dahm. et al., 2003). These two factors are fundamental for hydrogeologists, who derive 


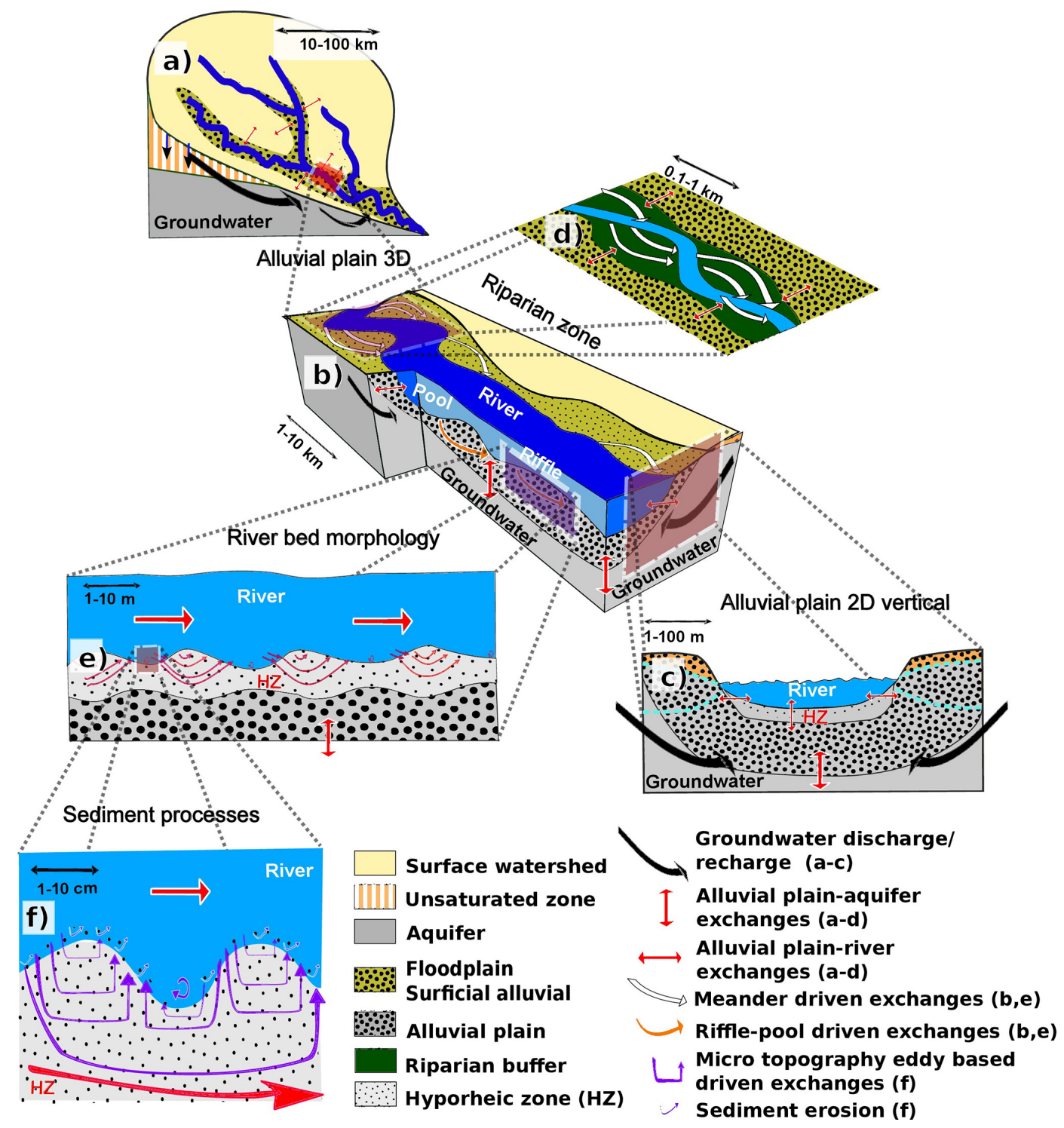

Figure 1. Nested stream-aquifer interfaces: (a) watershed-basin scale, (b) intermediate-reach scale in an alluvial plain, (c) cross section of the stream-aquifer interface, (d) meandered reach scale, (e) longitudinal river-HZ exchanges, (f) water column-sediment scale. Inspired by Stonedahl et al. (2010).

subsurface flow velocities and transfer times from those factors. The timescale to be considered also varies depending on the studied object (HZ itself or a sedimentary basin functioning) (Harvey, 2002). Estimating the stream-aquifer exchanges at a sedimentary basin scale then requires the combination of various processes with different characteristic times or periods covering a wide range of temporal orders of magnitude (Blöschl and Sivapalan, 1995; Cardenas, 2008b; Flipo et al., 2012; Massei et al., 2010): hour-day for river processes, year-decade for effective rainfall, decade-century for subsurface transit time.

Mouhri et al. (2013) proposed a multi-scale framework to study stream-aquifer interfaces. Their approach is based on the observation that the two main hydrosystem components are the surface and groundwater components, which are connected by nested interfaces (Fig. 1) leading to patterns in residence time over the scales (Cardenas, 2008b). Stream-aquifer interfaces consist of alluvial plain at the regional and watershed scales (Fig. 1a and b), while within the alluvial plain, they consist of riparian zone at the reach scale (Fig. 1d). Within the riparian zone, they consist of the hyporheic zone at the local scale (Fig. 1c), and so on, until the water column-benthos interface within the river itself (Fig. 1f). The concept of nested stream-aquifer interfaces includes the hydrologic spiralling concept of Poole et al. (2008) into the nested groundwater pathways vision 
of Tóth (1963), recently revisited to account for multi-scale anisotropy (Zlotnik et al., 2011). Before further developing the multi-scale framework, the various descriptions of stream-aquifer interfaces are outlined from the local to the continental scale. A classification by order of importance of heterogeneity controls on stream-aquifer water exchanges is proposed in Sect. 2.6.

\subsection{The stream-aquifer interface at the local scale - the hyporheic zone}

At the local scale (plot, river cross section), the streamaquifer interface consists of a hyporheic zone (HZ, Fig. 1c), which corresponds to an ecotone, whose extent varies dynamically in space and time. This ecotone is at the interface between two more uniform, yet contrasted ecological systems (Brunke and Gonser, 1997): the river and the aquifer. In a broad sense, the $\mathrm{HZ}$ is "the saturated transition zone between surface water and groundwater bodies that derives its specific physical (e.g. water temperature) and biogeochemical (e.g. steep chemical gradients) characteristics from active mixing of surface and groundwater to provide a habitat and refugia for obligate and facultative species" (Krause et al., 2009a, p. 2103). White (1993) also indicates that the HZ is located beneath the streambed and in the stream banks that contain infiltrated stream water. Furthermore, Malard et al. (2002) identified five generic HZ configurations, that depend on the structure of the subsurface medium, and especially on the location of the impervious substratum:

1. No HZ: the stream flows directly on the impervious substratum. A perennial lateral HZ can appear in a zone of significant longitudinal curvature of the stream, for instance in the case of meanders (Sect. 2.3.1).

2. No aquifer unit: a $\mathrm{HZ}$ can appear due to the infiltration of the stream water towards the substratum or through the stream banks. In the former case, the substratum is located near the streambed sediments.

3. Existence of a HZ in a connected stream-aquifer system: the $\mathrm{HZ}$ is created by advective water from both the stream and the aquifer unit. The impervious substratum is located beneath the aquifer unit.

4. Existence of a $\mathrm{HZ}$ in a disconnected stream-aquifer system: a distinct porous medium lies in between the streambed and the aquifer unit. This porous medium would not be saturated if the streambed were impervious. In this configuration, two subcategories are to be found:

a. the vertical infiltration of stream water towards the top of the aquifer unit generates a zone of mixing waters at the top of the aquifer unit, far enough below the streambed to be disconnected from it; b. a perched HZ is formed below the streambed due to the infiltration of stream water; in this particular case, the porous medium below the streambed is either very thick or its conductive properties are so poor that the surface water may not reach the aquifer unit.

Hydro-sedimentary processes generate heterogeneous, usually layered, streambed (Hatch et al., 2010; Sawyer and Cardenas, 2009). In situ measurements revealed that the streambed permeabilities range over several order of magnitude both vertically and horizontally (Leek et al., 2009; Ryan and Boufadel, 2007; Sawyer and Cardenas, 2009; Sebok et al., 2014). These heterogeneities favour horizontal flow paths rather than vertical flow paths (Marion et al., 2008; Ryan and Boufadel, 2006), leading to a stratification of chemical concentration in the streambed (Ryan and Boufadel, 2006). Overall, the heterogeneities modify both the penetration depth and the residence time of streamaquifer exchanges (Cardenas et al., 2004; Salehin et al., 2004; Sawyer and Cardenas, 2009). The common hypothesis of an homogeneous bed therefore generates errors on the assessment of stream-aquifer exchanges (Cardenas et al., 2004; Frei et al., 2010; Kalbus et al., 2009; Irvine et al., 2012), which are difficult to estimate for real case studies due to the fact that small scale heterogeneities are difficult to assess.

Coupled to the structural heterogeneities, the microtopography of the streambed modulates the exchanges longitudinally (Fig. 1f), due to the occurrence of advective pumping (Cardenas and Wilson, 2007a, b; Endreny et al., 2011; Janssen et al., 2012; Käser et al., 2013; Krause et al., 2012b; Munz et al., 2011; Sawyer and Cardenas, 2009; Stonedahl et al., 2010).

\subsection{The stream-aquifer interfaces at the intermediate scale - the hyporheic corridor}

At the intermediate scale, the stream-aquifer interface consists of a complex mosaic of surface and subsurface flow paths of variable length, depth, residence time, and direction, composing the hydrological spiralling concept of Poole et al. (2008). These flow paths are controlled by the geometrical shapes and the hydraulic properties of the structural heterogeneities. Confronted with such complexity, Brunke and Gonser (1997) and Stanford and Boulton (1993) developed the concept of "hyporheic corridor", which considers not only the river, but also its extension as a continuum (Bencala et al., 2011; Malard et al., 2002) in the form of alluvial flow paths maintaining biodiversity patterns and ecosystem metabolism. The hyporheic corridor extends the 2-D hyporheic zone (previous section) to a dynamical 3-D system, which links the actual hydro-sedimentary behaviour of the river to its mid-term and long-term history by the means of 
the sediment heterogeneities within the alluvial plain and the associated water pathways.

\subsubsection{Morphological shaping related to the hydro-sedimentary river dynamics}

At the local scale, the hyporheic exchanges are described by 2-D water pathways across the heterogeneous streambed and river banks. However, at the reach scale, rivers develop a complex geometry, such as meander belts, which transforms the vertical 2-D understanding of hydrological processes (Fig. 1c) into a more complicated 3-D system involving lateral water pathways (Fig. 1d).

At the reach scale, hyporheic exchanges therefore develop in various geomorphological structures, such as stream curvature (Fig. 1d), as well as in-stream pool and riffle sequences and sediment bars (Fig. 1e). Each of these structures significantly affects stream-aquifer exchanges (Stonedahl et al., 2010) involving a specific transfer time (Cardenas, 2008b).

As stated by Rubin et al. (2006), there is "a hierarchy of different bedform sizes in rivers", consisting of ripples, dunes, and compound bars. These forms are related, through river morphological characteristics such as width, cross section, and slope, to hydro-sedimentary processes taking place in the river and forming strata sets (Bridge and Best, 1997; Paola and Borgman, 1991; Rubin et al., 2006).

Due to the longitudinal water head decrease along the flow, pool and riffle sequences are submitted, from upstream to downstream, to a head gradient, which involves water downwelling upstream riffles and water upwelling at the riffle tail (Crispell and Endreny, 2009; Frei et al., 2010; Gooseff et al., 2006; Harvey and Bencala, 1993; Gariglio et al., 2013; Kasahara and Hill, 2006; Maier and Howard, 2011; Marzadri et al., 2011; Saenger et al., 2005; Tonina and Buffington, 2007). Due to the sequence, stream-aquifer exchanges seem to increase with the amplitude of the streambed oscillations, until a threshold is reached (Trauth et al., 2013). Also, combined streambed oscillating frequencies may increase the intensity of the exchanges in a complex way (Käser et al., 2013). Bedform-induced hyporheic exchanges can be viewed as longitudinally $2-\mathrm{D}$ vertical processes. Similar 2-D horizontal processes also occur in single or alternating unit bars (Burkholder et al., 2008; Cardenas, 2009a; Deforet et al., 2009; Derx et al., 2010; Marzadri et al., 2010; Shope et al., 2012) or bedform discontinuities (Hester and Doyle, 2008).

The development of a hyporheic zone inside a meander belt was recently simulated to estimate the water pathways involved in such a hyporheic flow (Boano et al., 2006; Revelli et al., 2008; Cardenas, 2008a). The numerical results of Cardenas (2008a) prove that the shape of the meander is responsible for the flow path length and the residence time distribution within the point bar. Only few exchanges and low discharges occur in the core of the meander, while the neck is characterised by intense water exchanges between the river and the sediments (Revelli et al., 2008). The effect of successive meanders on water pathways and travel times was also simulated in an homogeneous alluvial aquifer (Cardenas, 2009a), which can help restoration projects involving channel modifications (Gomez et al., 2012). The sinuosity of the stream depends on its functioning and the characteristics of its alluvial plain.

Although the stream morphological heterogeneities are of primary importance for the quantification of the water fluxes in the hyporheic corridor (Kasahara and Wondzell, 2003; Lautz and Siegel, 2006; Tonina and Buffington, 2011; Wondzell et al., 2009), the understanding of the streamaquifer interactions also relies on a proper characterisation of the physical flow properties of alluvial plains and their various geomorphological units (Anderson et al., 1999).

\subsubsection{Hydrofacies related to the alluvial plain architecture}

Alluvial plains are the result of the sedimentary infilling of valleys cut into the bedrock. In Quaternary coastal settings, cutting and filling respond strongly to base-level fluctuations driven by glacioeustatic sea-level changes (Schumm, 1993; Dalrymple, 2006). For upstream alluvial valleys beyond the influence of sea-level fluctuations, cutting and filling reflect complex interactions between climate, tectonics, sediment supply and river drainage changes (Gibling et al., 2011). Sediment heterogeneity within the alluvial plains is produced by the transport and depositional processes that have operated in different palaeogeomorphic settings within the fluvial system. This results in a complex stacking of lithofacies, bounded by erosional and depositional surfaces. These lithofacies are composed of sediments ranging over a broad scale of grain size and sorting, and can be described in terms of hydraulic parameters (e.g. conductivity), defining a hydrofacies (Anderson et al., 1999; Hornung and Aigner, 1999; Klingbeil et al., 1999; Heinz et al., 2003; Fleckenstein et al., 2006). Sediment heterogeneity can thus produce sharp contrasts in hydraulic conductivity of several orders of magnitude (Miall, 1996). Different scales of sediment heterogeneity are nested within an alluvial plain (Koltermann and Gorelick, 1996): grain segregation in bedload and turbulent fluctuations of the flow produce heterogeneous cross-stratification within bedforms at the centimetre scale (Allen, 1963, 1966). Sand and gravel bar internal structures reflect the distribution of the sediment load in the water column, the succession of different flow stages, and the morphodynamic interactions with other bars and cross-bar channels (Bridge, 2006). Their sizes, highly variable but proportional to the channel size, range between several tens to several hundreds of metres. At the kilometre scale, fine overbank deposits and abandoned channels filled with high organic content clays produce sharp lithological contrasts with the coarser channelised facies.

The nature of sediment heterogeneity is closely linked to the functioning of the river channel and its associated 
floodplain, controlled by hydro-climatic, geologic and geomorphologic conditions at the regional scale (Nanson and Croke, 1992). The degree of heterogeneity at the regional scale between coarse channelised facies and less permeable floodplain deposits mainly depends on the ratios between the rate of lateral migration of the river channel, the rate of vertical accretion by overbank deposits, the avulsive behaviour of the fluvial system, and the degree of confinement of the floodplain (Bristow and Best, 1993; Miall, 1996). The substratum on which the channel migrates (containing the hyporheic zone), is thus composed of sediments representative either of an alluvial plain contemporaneous with present hydroclimatic conditions, or of relict floodplain elements formed under prior river flow regimes (Brunke and Gonser, 1997; Nanson and Croke, 1992; Woessner, 2000).

The streambed heterogeneities, coupled with the longitudinal variation of the bed, impact the dynamics of the streamaquifer exchanges by creating complex flow paths (Salehin et al., 2004) as flow recirculation (Cardenas et al., 2004). In the case of a meandering channel, sediment deposition on the inner meander bank results in the formation of a permeable point-bar, the texture and architecture of which reflects the flow characteristics and the sediment size distribution within the water column. On the outer eroded bank, the sediment is composed of older deposits, the composition of which eventually reflects the past history of construction of the alluvial plain. This specific configuration creates asymmetrical stream-aquifer interactions between the two river banks (O'Driscoll et al., 2010), and, depending on the outer bank sediment heterogeneities, can generate preferential flow paths in the alluvial plain (Peterson and Sickbert, 2006).

The spatial distribution of porosity and transmissivity, associated with sediment heterogeneities, impacts the dynamics of the stream-aquifer exchanges by creating flow recirculations both vertically across the streambed and horizontally across the channel banks. Along with the sediment heterogeneities, the geomorphological structures of the alluvial plain can also create preferential pathways, which can have a significant impact on stream-aquifer exchanges (Conant, 2004; Fleckenstein et al., 2006; Krause et al., 2007; Poole et al., 2002, 2008; Storey et al., 2003; van Balen et al., 2008; Weng et al., 2003; Woessner, 2000). Overall, the preferential flow paths lead to a spatially and temporally complex piezometric head distribution in the alluvial plain, especially during transitional event as floods (Bendjoudi et al., 2002; Heeren et al., 2014; Koch et al., 2011; Wondzell and Swanson, 1999; Wroblicky et al., 1998), when bank storage occurs (Whiting and Pomeranets, 1997).

\subsection{The stream-aquifer interfaces at the regional scale - buffering effect of alluvial plains}

The pioneering work of Tóth (1963) showed that topography, geology and climate are major control factors of hierarchically nested groundwater flow systems: local, intermediate and regional. These nested flow systems are gravity driven from uphill to downhill. The piezometric surface of the groundwater near the alluvial plain usually flattens and becomes highly correlated to the soil surface topography (Tóth, 1962). It remains to locate the lowest piezometric level in the downhill alluvial plain, where the hyporheic corridor develops. The complex piezometric head distribution of the hyporheic corridor constitutes the boundary conditions for the exchanges between the alluvial plain and the underlying regional aquifer system. In this configuration, the river is not always representative of the lowest piezometric head in the hyporheic corridor. For instance, Curie et al. (2009) report a case study in which alluvial ground waters and stream waters were converging to a zone parallel to the stream, which acts as a drainage pathway inside the alluvial plain. In this specific case, the drainage pathway is the lowest piezometric head. It thence controls the exchanges between the regional aquifer and the alluvial one.

Moreover, longitudinal changes in the width and in the depth of the alluvial plain along the hyporheic corridor modify the piezometric head gradient of the hyporheic corridor at the kilometre scale (Malard et al., 2002; Woessner, 2000), which also influences the exchanges between the alluvial plain and the regional aquifer spatially. In addition to the complex behaviour of nested flow systems, Zlotnik et al. (2011) prove that small-scale anisotropy prevents or amplifies the flow patterns due to large-scale aquifer anisotropy.

These complex interactions between, on the one side, the river network and the hyporheic corridor, and on the other side, the hyporheic corridor and the regional aquifer system, contribute to the riparian turnover mentioned by Jencso et al. (2010). It characterises the fact that alluvial aquifers behave as a buffering zone between low frequency processes occurring at the regional scale and high frequency processes occurring in the river network. The flow patterns resulting from this complex interaction can be evaluated by water transit time (Haitjema, 1995; McGuire and McDonnell, 2006) or using tracers (Macpherson and Sophocleous, 2004).

\subsection{The stream-aquifer interface at the continental scale - the closure of the continental hydrological cycle}

At the continental scale, the complex dynamics of streamaquifer exchanges might have consequences on the proper closure of the hydrological cycle, which partly consists in assessing groundwater and surface water pathways and travel time. Currently, a large range of satellite data allows the remote observation of the continental hydrological cycle, temporarily from the seasonal to the decennial scale, and spatially from the sub-kilometre (Brunner et al., 2008) to the continental scale (García-García et al., 2011). Even if satellites cannot measure the stream-aquifer exchanges directly, they provide valuable ancillary data, especially for obtaining information on temporal and spatial low frequency 
variabilities. They might also be a source of information crucial for ungauged or poorly gauged large basins, as for example the Congo River (O'Loughlin et al., 2013) or other big monsoon rivers.

For example, total water storage (e.g. surface water and ground water) variations can be estimated from the Gravity Recovery and Climate Experiment (GRACE) mission, launched in 2002 (Tapley et al., 2004). Examples of space borne based hydrological studies can be found in Ramillien et al. (2008), who provide an extensive review of large-scale hydrological use of the first years of GRACE data. These data have coarse spatial $(300-400 \mathrm{~km})$ and temporal (from 10 days to 1 month) resolutions (Ramillien et al., 2012), but cover all continental surfaces, making their use particularly suitable at continental or large river basin scales. Yet, as GRACE data correspond to changes in total water storage, they have to be coupled with ancillary information to distinguish between surface water and ground water variations.

For the specific stream-aquifer exchanges, satellite observations of water extents and water elevations might be the most straightforward data to use. Current nadir altimeter satellites provide estimates of surface elevation (but not water depth) above a given reference datum of big water bodies crossed by the satellite ground track (Calmant et al., 2008), the instrument footprint being around $1 \mathrm{~km}$. These measurements have a repeatability depending on the satellite orbit, which typically ranges from 10 to 35 days. Recent attempts have also demonstrated the possibility to estimate water storage variations by combining multi-sensor measurements. Optical or radar images are used to compute water extent (Cretaux et al., 2011) and can be combined with a digital elevation model (DEM) or with water elevation measurements from nadir altimeters to derive storage changes and fluxes (Neal et al., 2009; Gao et al., 2012). Yet, satellites providing water surface extents and the ones measuring water elevations do not have the same repeatability and spatial coverage, introducing errors in water storage variation estimates and limiting assessment of stream-aquifer exchanges at the continental scale.

To overcome this last issue, a new space borne mission, the Surface Water and Ocean Topography (SWOT) mission, is currently being developed by NASA, CNES (French Spatial Agency), CSA (Canadian Space Agency) and UKSA (UK Space Agency), for a planned launch in 2019. SWOT will provide maps of distributed water elevations, water extents and water slopes on two swaths of $50 \mathrm{~km}$ each. It will enable the observation of rivers wider than $100 \mathrm{~m}$ and surface areas larger than $250 \mathrm{~m} \times 250 \mathrm{~m}$ (Rodríguez, 2014). Accuracies on water elevation and water slope will be around $10 \mathrm{~cm}$ and $1 \mathrm{~cm} \mathrm{~km}^{-1}$, respectively, after averaging over $1 \mathrm{~km}^{2}$ water area (Rodríguez, 2014). From these requirements, Biancamaria et al. (2010) estimated that SWOT should be able to provide useful information to compute discharge for river reaches with drainage areas above $70000 \mathrm{~km}^{2}$. This preliminary assessment was recently refined by Andreadis et al.
(2013), who estimate that rivers with a bank full width of $100 \mathrm{~m}$ have drainage area ranging from 1050 to $50000 \mathrm{~km}^{2}$. Although the database contains errors (reported errors on river width range from 8 to $62 \%$ ), it provides the order of magnitude of minimum drainage area that will be sampled by SWOT. Given the two swaths and its 21 day orbit, the instrument will observe almost all continental surfaces in between $78^{\circ} \mathrm{S}$ and $78^{\circ} \mathrm{N}$, allowing the sampling of all drainage areas above $50000 \mathrm{~km}^{2}$.

More information on the usage of these satellite data is given within the MIM framework in Sect. 4.2.

\subsection{A multi-scale issue structured around the river network}

As developed in Sect. 2.3, the hyporheic corridor, closely related to the river network, is identified as being the location where flow paths mix at all scales. Consequently, it is the location of hydrological processes scaling.

Near-river groundwater flow paths are mainly controlled by regional flow paths in aquifer systems (Malard et al., 2002). Indeed, the groundwater component of a hydrosystem controls the regional flows towards the alluvial plains and the rivers. Such flow paths define the total amount of water that flows in the stream-aquifer interface (Cardenas and Wilson, 2007b; Frei et al., 2009; Kalbus et al., 2009; Rushton, 2007; Storey et al., 2003). This is not a new concept, as the river network corresponds to drains collecting regional groundwater (Fig. 1a), which sustain the network during low flow period (Ellis et al., 2007; Pinder and Jones, 1969; Tóth, 1963). These large-scale structural heterogeneities can also generate local conditions that favour local re-infiltration of river water towards the aquifer system (Boano et al., 2010a; Cardenas, 2009a; Cardenas, 2009b; Fleckenstein et al., 2006). These re-infiltrations (Fig. 1b and c) can even constitute the main recharge of some peculiar local aquifer systems, as for instance some alluvial plain (Krause and Bronstert, 2007; Krause et al., 2007).

In a second instance, the spatial distribution of the streambed permeabilities controls the dynamics of streamaquifer exchanges within the alluvial plain, and therefore the near-river piezometric head distribution (Calver, 2001; Fleckenstein et al., 2006; Frei et al., 2009; Genereux et al., 2008; Hester and Doyle, 2008; Kalbus et al., 2009; Käser et al., 2009; Rosenberry and Pitlick, 2009). Finally, the longitudinal morphology of the river and the topography of the riverbed, consisting of a pluri-metric succession of pools and riffles (Fig. 1e), also impact the stream-aquifer exchanges (Crispell and Endreny, 2009; Frei et al., 2010; Gooseff et al., 2006; Harvey and Bencala, 1993; Kasahara and Hill, 2006; Käser et al., 2013; Maier and Howard, 2011; Tonina and Buffington, 2007), until a threshold of streambed amplitudes is reached (Trauth et al., 2013). Likewise, the depth of the alluvial aquifer (Koch et al., 2011; Marzadri et al., 2010; Whiting and Pomeranets, 1997), and the river hydraulic 
regime (Cardenas and Wilson, 2007a; Munz et al., 2011; Saenger et al., 2005) influence stream-aquifer exchanges. Ultimately a very fine scale process $(\sim \mathrm{cm}-\mathrm{dm})$, due to the in-stream nonhydrostatic flow induced by bedform microtopography (Fig. 1f), increases the absolute value of the total stream-aquifer exchanges (Cardenas and Wilson, 2007a, b; Endreny et al., 2011; Janssen et al., 2012; Käser et al., 2013; Krause et al., 2012b; Sawyer and Cardenas, 2009; Stonedahl et al., 2010).

It is thus important to study the stream-aquifer exchanges from the dual perspective of regional and local exchanges; the former being controlled by regional recharge and structural heterogeneities, the latter by the longitudinal distribution of streambed heterogeneities and the river morphology (Schmidt et al., 2006). These two types of control factors may also generate water loops within the stream-aquifer interfaces, the hyporheic corridor being the location where these processes merge (Poole et al., 2008).

\section{Modelling stream-aquifer exchanges}

A literature review of process-based modelling of streamaquifer interfaces' functioning is presented in Table 1, which synthesises 51 references. The majority of these focus on the local scale (25), while only four consider the regional and continental scales. The remaining mostly focus on the localintermediate (11) and intermediate scales (11).

\subsection{Overview of coupled surface-subsurface hydrological models}

Many hydrosystem models have been developed, in particular coupled surface-subsurface hydro(geo)logical models (Loague and VanderKwaak, 2004), with no special emphasis on stream-aquifer interfaces.

During the 1970s and 1980s, the first sedimentary basin distributed physically-based models (DPBMs) were developed based on the finite differences numerical scheme (Abbott et al., 1986; Freeze, 1971; Harbaugh et al., 2000; Ledoux et al., 1989; de Marsily et al., 1978; McDonald and Harbaugh, 1988; Parkin et al., 1996; Perkins and Sophocleous, 1999; Refsgaard and Knudsen, 1996). In this type of approach, the hydrosystem is divided into compartments, which exchange through interfaces.

Since the late 1990s, new models based on finite element numerical schemes have been developed (Bixio et al., 2002; Goderniaux et al., 2009; Kolditz et al., 2008; Kollet and Maxwell, 2006; Li et al., 2008; Panday and Huyakorn, 2004; Therrien et al., 2010; VanderKwaak and Loague, 2001; Weill et al., 2009). These models allow the simulation of the pressure head in 3-D instead of the former pseudo 3-D modelling of the piezometric head. However, it is not yet possible to straightforwardly simulate large hydrosystems $\left(>10000 \mathrm{~km}^{2}\right)$ with a high spatio-temporal resolution for long periods of time (a few decades) (Flipo et al., 2012). This is due to the large number of elements required to simulate such hydrosystems (Gunduz and Aral, 2005), which imposes the usage of heavily parallelised codes for simulating these systems with such a spatio-temporal resolution. Recently, a proof of concept has been published by Kollet et al. (2010), who have simulated a $1000 \mathrm{~km}^{2}$ basin with a high spatiotemporal resolution.

\subsection{Models for simulating stream-aquifer interface}

Surface water-groundwater exchanges, mostly through the soil or the stream-aquifer interface, are simulated with two different models (Ebel et al., 2009; Kollet and Maxwell, 2006; LaBolle et al., 2003; Furman, 2008):

- A conductance model or first-order exchange coefficient (Rushton and Tomlinson, 1979), for which the interface is described with a water conductivity value. The exchanged water flux is then calculated as the product of the conductivity by the difference of piezometric heads between the aquifer and the surface water body. Depending on the model, the difference of pressures can also be used. This model implicitly formulates the hypothesis of a vertical water flux between surface water and groundwater, whatever the mesh size. This is the most common model for simulating stream-aquifer exchanges. There are diverse conductance formulations, especially in the case of disconnected aquifers and streams (Osman and Bruen, 2002). The conductance model usually assumes an equivalent homogeneous riverbed for the definition of the conductance value, which can imply estimation errors in the exchanged water fluxes compared to a more realistic heterogeneous riverbed. However, if the model is appropriately calibrated with regard to the connection/disconnection status, this assumption leads to slight estimation errors (Irvine et al., 2012). Another potential drawback of the conductance model is that the conductance coefficient depends on the temperature because it implicitly integrates the fluid viscosity (Doppler et al., 2007; Engeler et al., 2011). Moreover, the validity of the first-order law is critical in the case of a flood when water expends in the flood plain (Doppler et al., 2007; Engeler et al., 2011).

- Continuity of pressures and fluxes at the interface. This boundary condition requires an iterative or a sequential computation, although the iterative one is more precise (Sulis et al., 2010). Sometimes the iterative process also leads to a discontinuity of the tangential component of the water velocity at the interface with the streambed (Discacciati et al., 2002; Miglio et al., 2003; Urquiza et al., 2008). This is not a problem, as this discontinuity can be interpreted as representative of the streambed load. It should also be noted that the validity of this 
Table 1. Physically based modelling of stream-aquifer exchanges.

\begin{tabular}{|c|c|c|c|c|c|c|}
\hline \multirow[t]{2}{*}{ Ref } & \multirow[t]{2}{*}{ Exch } & \multirow[t]{2}{*}{ Spec } & \multicolumn{2}{|l|}{ Resolution } & \multirow[t]{2}{*}{ Scale } & \multirow[t]{2}{*}{$\mathrm{CS}$} \\
\hline & & & $\Delta x$ & $\Delta t$ & & \\
\hline Brunner et al. (2009a, b) & $\mathrm{K}$ & 2-D V LAT & {$[1-100] \mathrm{m} \times[\leq 0.05] \mathrm{m}$} & perm & loc-int & $\mathrm{S}$ \\
\hline Brunner et al. (2010) & $\mathrm{K}$ & 2-D V LAT & {$[1-10] \mathrm{m} \times[0.1-10] \mathrm{m}$} & perm & loc-int & $\mathrm{S}$ \\
\hline Cardenas et al. (2004) & $\mathrm{K}$ & $3-\mathrm{D}$ & $0.25 \mathrm{~m} \times 0.25 \mathrm{~m} \times 0.04 \mathrm{~m}$ & perm & loc & $S$ \\
\hline Cardenas and Wilson $(2007 b, c)$ & $\mathrm{P}$ & 2-D V LON & $0.01 \mathrm{~m} \times 0.01 \mathrm{~m}^{*}$ & perm & loc & $S$ \\
\hline Cardenas (2009a) & $\mathrm{P}$ & 2-D H & $\mathrm{NS}(80 \mathrm{~m} \times 45 \mathrm{~m})$ & perm & loc & $S$ \\
\hline Chen and Chen (2003) & $\mathrm{K}$ & $3-\mathrm{D}$ & {$[3-6] \mathrm{m} \times[3-6] \mathrm{m} \times[6.7-7.6] \mathrm{m}$} & $\min$ & loc-int & $\mathrm{R}$ \\
\hline Derx et al. (2010) & $\mathrm{K}$ & $3-\mathrm{D}$ & {$[5-100] \mathrm{m} \times[5-100] \mathrm{m} \times[5-40] \mathrm{cm}$} & $30 \mathrm{~min}$ & int & $\mathrm{R}$ \\
\hline Diem et al. (2014) & $\mathrm{K}$ & $3-\mathrm{D}$ & {$[1-10] \mathrm{m} \times[1-10] \mathrm{m} \times[1-10] \mathrm{m}$} & adapt & int & $\mathrm{R}$ \\
\hline Discacciati et al. (2002) & $\mathrm{P}$ & $3-\mathrm{D}$ & {$[0.5-5] \mathrm{m} \times[0.5-5] \mathrm{m} \times[0.3-1.5] \mathrm{m} *$} & perm & loc & $S$ \\
\hline Doppler et al. (2007) & $\mathrm{K}$ & 2-D H & {$[1-50] \mathrm{m} \times[1-50] \mathrm{m}$} & $1 \mathrm{~d}$ & int & $\mathrm{R}$ \\
\hline Ebel et al. (2009) & $\mathrm{K}$ & $3-\mathrm{D}$ & {$[1-20] \mathrm{m} \times[1-20] \mathrm{m} \times[0.05-0.25] \mathrm{m}$} & adapt & loc-int & $\mathrm{R}$ \\
\hline Engeler et al. (2011) & $\mathrm{K}$ & $3-\mathrm{D}$ & {$[1-50] \mathrm{m} \times[1-50] \mathrm{m} \times[1.6-40] \mathrm{m}$} & $900 \mathrm{~s}$ & int & $\mathrm{R}$ \\
\hline Fleckenstein et al. (2006) & $\mathrm{K}$ & $3-\mathrm{D}$ & $200 \mathrm{~m} \times 100 \mathrm{~m} \times[5-40] \mathrm{m}$ & $3 \mathrm{~h}$ & int & $\mathrm{R}$ \\
\hline Frei et al. (2009) & $\mathrm{P}$ & $3-\mathrm{D}$ & $20 \mathrm{~m} \times 50 \mathrm{~m} \times 0.5 \mathrm{~m}$ & $\min$ & int & $S$ \\
\hline Frei et al. (2010) & $\mathrm{K}$ & $3-\mathrm{D}$ & $0.1 \mathrm{~m} \times 0.1 \mathrm{~m} \times 0.1 \mathrm{~m}$ & adapt & loc & $S$ \\
\hline Gooseff et al. (2006) & $\mathrm{K}$ & 2-D V LON & $0.20 \mathrm{~m} \times[0.3-0.5] \mathrm{m}$ & perm & loc & $S$ \\
\hline Hester and Doyle (2008) & $\mathrm{K}$ & 2-D V LON & $3 \mathrm{~m} \times[0.1-0.25] \mathrm{m}$ & perm & loc & $S$ \\
\hline Irvine et al. (2012) & $\mathrm{K}$ & $3-\mathrm{D}$ & $0.5 \mathrm{~m} \times[0.5-2.6] \mathrm{m} \times[0.03-0.7] \mathrm{m}$ & perm & loc & $S$ \\
\hline Janssen et al. (2012) & $\mathrm{P}$ & 2-D V LON & $2 \mathrm{~mm} \times 2 \mathrm{~mm}$ & perm & loc & $\mathrm{L}$ \\
\hline Kalbus et al. (2009) & $\mathrm{K}$ & 2-D V LON & $1 \mathrm{~m} \times[0.05-0.2] \mathrm{m}$ & perm & loc & $\mathrm{S}$ \\
\hline Kasahara and Wondzell (2003) & $\mathrm{K}$ & $3-\mathrm{D}$ & {$[0.3-0.5] \mathrm{m} \times[0.3-0.5] \mathrm{m} \times[0.15-0.3] \mathrm{m}$} & perm & loc-int & $\mathrm{R}$ \\
\hline Kasahara and Hill (2006) & $\mathrm{K}$ & $3-\mathrm{D}$ & {$[0.6-3.5] \mathrm{m} \times[0.2-0.5] \mathrm{m} \times 0.15 \mathrm{~m}$} & perm & loc & $\mathrm{R}$ \\
\hline Käser et al. (2013) & $\mathrm{P}$ & 2-D V LON & $0.78 \mathrm{~cm} \times[0.78-100] \mathrm{cm}$ & perm & loc & $\mathrm{S}$ \\
\hline Koch et al. (2011) & $\mathrm{K}$ & $3-\mathrm{D}$ & $\mathrm{NS}(1.7 \mathrm{~km} \times 200 \mathrm{~m} \times 0.5 \mathrm{~m})$ & $1 \mathrm{~h}$ & int & $\mathrm{R}$ \\
\hline Krause and Bronstert (2007) & $\mathrm{K}$ & 2-D H & {$[25-50] \mathrm{m} \times[25-50] \mathrm{m}$} & $1 \mathrm{~h}$ & int & $\mathrm{R}$ \\
\hline Krause et al. (2007) & $\mathrm{K}$ & 2-D H & {$[25-250] \mathrm{m} \times[25-250] \mathrm{m}$} & $1 \mathrm{~h}$ & int-reg & $\mathrm{R}$ \\
\hline Lautz and Siegel (2006) & $\mathrm{K}$ & $3-\mathrm{D}$ & $0.5 \mathrm{~m} \times 0.5 \mathrm{~m} \times[0.6-2] \mathrm{m}$ & perm & loc-int & $\mathrm{R}$ \\
\hline Maier and Howard (2011) & $\mathrm{K}$ & 2-D H & {$[1-7] \mathrm{m} \times[1-5] \mathrm{m} \times[0.1-10] \mathrm{m}$} & perm & loc-int & $\mathrm{R}$ \\
\hline Marzadri et al. (2010) & $\mathrm{K}$ & $3-\mathrm{D}$ & {$[0.19-1.88] \mathrm{m} \times[0.06-0.5] \mathrm{m} \times[0.1] \mathrm{m}$} & perm & loc-int & $\mathrm{S}$ \\
\hline Marzadri et al. (2011) & $\mathrm{K}$ & $3-\mathrm{D}$ & $\mathrm{NS}(16.9 \mathrm{~m} \times 2.6 \mathrm{~m} \times 1.6 \mathrm{~m})$ & perm & loc & $S$ \\
\hline Miglio et al. (2003) & $\mathrm{P}$ & $3-\mathrm{D}$ & {$[0.2-0.5] \mathrm{m} \times[0.2 \times 0.5] \mathrm{m} \times[0.05-0.15] \mathrm{m}^{*}$} & $600 \mathrm{~s}$ & loc & $S$ \\
\hline Mouhri et al. (2013) & $\mathrm{P}$ & $2-\mathrm{D} \mathrm{V}$ & {$[0.01-0.1] \mathrm{m} \times[0.01 \times 0.1] \mathrm{m}$} & $\min$ & loc & $\mathrm{R}$ \\
\hline Munz et al. (2011) & $\mathrm{K}$ & $3-\mathrm{D}$ & $0.5 \mathrm{~m} \times 0.5 \mathrm{~m} \times[0.1-2.48] \mathrm{m}$ & $1 \mathrm{~h}^{*}$ & loc & $\mathrm{R}$ \\
\hline Osman and Bruen (2002) & $\mathrm{K}$ & 2-D V LAT & $\mathrm{NS}(360 \mathrm{~m} \times 21 \mathrm{~m})$ & perm & loc & $S$ \\
\hline Peyrard et al. (2008) & $\mathrm{P}$ & 2-D H & {$[10-40] \mathrm{m} \times[10-40] \mathrm{m}$} & adapt & int & $\mathrm{R}$ \\
\hline Pryet et al. (2014) & $\mathrm{K}$ & 2-D H & $1 \mathrm{~km} \times 1 \mathrm{~km}$ & $1 d$ & reg & $\mathrm{R}$ \\
\hline Revelli et al. (2008) & $\mathrm{K}$ & 2-D H & $\mathrm{NS}([0.22-4.4] \mathrm{km} \times[0.19-3.8] \mathrm{km})$ & perm & int & $S$ \\
\hline Rushton (2007) & $\mathrm{K}$ & 2-D V LAT & $20 \mathrm{~m} \times 0.2 \mathrm{~m}$ & perm & loc-int & $\mathrm{S}$ \\
\hline Saenger et al. (2005) & $\mathrm{K}$ & V LON & $0.1 \mathrm{~m} \times 0.02 \mathrm{~m}$ & perm & loc & $\mathrm{R}$ \\
\hline Saleh et al. (2011) & $\mathrm{K}$ & 2-D H & {$[1-4] \mathrm{km} \times[1-4] \mathrm{km} \times[-] \mathrm{m}$} & $1 \mathrm{j}$ & reg & $\mathrm{R}$ \\
\hline Sawyer and Cardenas (2009) & $\mathrm{P}$ & 2-D V LON & $0.01 \mathrm{~m} \times 0.005 \mathrm{~m}^{*}$ & perm & loc & $\mathrm{L}$ \\
\hline Storey et al. (2003) & $\mathrm{K}$ & $3-\mathrm{D}$ & {$[1-8] \mathrm{m} \times[1-8] \mathrm{m} \times[0.25-0.42] \mathrm{m}$} & perm & loc & $\mathrm{R}$ \\
\hline Sulis et al. (2010) & $\mathrm{K}, \mathrm{P}$ & $3-\mathrm{D}$ & {$[1-80] \mathrm{m} \times[1-80] \mathrm{m} \times[0.0125-0.5] \mathrm{m}$} & adapt & loc-int & $S$ \\
\hline Tonina and Buffington (2007) & $\mathrm{P}$ & $3-\mathrm{D}$ & $0.03 \mathrm{~m} \times 0.03 \mathrm{~m} \times 0.03 \mathrm{~m}$ & perm & loc & $\mathrm{L}$ \\
\hline Trauth et al. (2013) & $\mathrm{P}$ & $3-\mathrm{D}$ & $0.2 \mathrm{~m} \times 0.2 \mathrm{~m} \times 0.1 \mathrm{~m}$ & perm & loc & $S$ \\
\hline Urquiza et al. (2008) & $\mathrm{P}$ & 2-D V LON & $1 \mathrm{~m} \times 1 \mathrm{~m}$ & perm & loc & $S$ \\
\hline Vergnes et al. (2012) & $\mathrm{K}$ & 2-D H & $0.5^{\circ} \times 0.5^{\circ}$ & $1 \mathrm{~d}$ & reg & $\mathrm{R}$ \\
\hline Vergnes and Decharme (2012) & $\mathrm{K}$ & 2-D H & $0.5^{\circ} \times 0.5^{\circ}$ & $1 \mathrm{~d}$ & con & $\mathrm{R}$ \\
\hline Wondzell et al. (2009) & $\mathrm{K}$ & $3-\mathrm{D}$ & {$[0.125-2] \mathrm{m} \times[0.125-2] \mathrm{m} \times[0.16-0.4] \mathrm{m}$} & perm & loc & $\mathrm{R}$ \\
\hline
\end{tabular}

Exch (stream-aquifer exchanges' model): K: conductance model; P: Pressure continuity; V: vertical; LAT: lateral; LON: longitudinal; H: horizontal. Resolution: NS: not specified (total extension between parenthesis); * cell size not specified in the paper.

Spec (Specificities) $\Delta x$ (spatial); $\Delta t$ (temporal): perm: steady state; adapt: adaptive time step.

Scale: loc: local; int: intermediate; reg: regional; con: continental.

CS (Case Study): S: synthetical; L: lab experiment; R: real. 
approach relies on the knowledge of structural heterogeneities constitutive of the stream-aquifer interface.

Recent numerical developments allow for solving the coupled surface and subsurface equations with a matrical system (Gunduz and Aral, 2005; Liang et al., 2007; Peyrard et al., 2008; Qu and Duffy, 2007; Spanoudaki et al., 2009; Yuan et al., 2008). This method can be used whatever the selected stream-aquifer interface model. Its main drawback is that it is computationally demanding and usually requires a parallelised model in order to simulate a real hydrosystem.

From a conceptual point of view, the conductance model allows us to better understand the hydrological processes occurring at the stream-aquifer interface (Delfs et al., 2012; Ebel et al., 2009; Liggett et al., 2012; Nemeth and SoloGabriele, 2003) and is equivalent to the continuity one in the case of a highly conductive interface. Moreover, it has the advantage of simplifying the definition of structural heterogeneities in models. While the conductance model is able to simulate connected or disconnected systems (Brunner et al., 2009a), Brunner et al. (2010) showed that the conductance model remains appropriate for disconnecting streams, but only if an unsaturated flow formulation is chosen. Otherwise the model leads to estimation errors for disconnecting systems.

\subsection{Temperature as a tracer of the flow - the local scale}

The study of heat propagation is a powerful tool for assessing stream-aquifer exchanges (Anderson, 2005; Constantz, 2008; Mouhri et al., 2013) based on the temperature used as a tracer of the flow. Coupled with in situ measurements, two methods, based on heat transport governing equations, are used to quantify stream-aquifer exchanges (Anderson, 2005):

1. Analytical models (Stallman, 1965; Anderson, 2005) are widely used to invert temperature measurements solving the 1-D heat transport equation analytically under simplifying assumptions (sinusoidal or steady boundary conditions and homogeneity of hydraulic and thermal properties) (Anibas et al., 2009, 2012; Becker et al., 2004; Hatch et al., 2006; Jensen and Engesgaard, 2011; Keery et al., 2007; Lautz et al., 2010; Luce et al., 2013; Rau et al., 2010; Schmidt et al., 2007; Swanson and Cardenas, 2011).

2. Numerical models which couple water flow equations in porous media with the heat transport equation in 2-D or 3-D. These models are divided into two categories based on the numerical scheme: finite differences (Anderson et al., 2011; Anibas et al., 2009; Constantz et al., 2002, 2013; Constantz, 2008; Ebrahim et al., 2013; Lewandowski et al., 2011; Mutiti and Levy, 2010; Rühaak et al., 2008; Schornberg et al., 2010) or finite elements (Kalbus et al., 2009; Mouhri et al., 2013).
These models have the advantage of calculating spatiotemporal stream-aquifer exchanges with the capability of accounting for the heterogeneities under transient hydrodynamical and thermal conditions.

The two approaches provide estimates of the conductance coefficient that best represents the stream-aquifer interface at the local scale.

\subsection{The conductance model at the regional scale}

Although the usage of DPBM covers a broad range of spatial scales, only 18 publications among 182 (Flipo, 2013) concern large river basins $\left(>10000 \mathrm{~km}^{2}\right.$ ) (Abu-El-Sha's and Rihani, 2007; Andersen et al., 2001; Arnold et al., 1999; Bauer et al., 2006; Carroll et al., 2009; Etchevers et al., 2001; Golaz-Cavazzi et al., 2001; Gomez et al., 2003; Habets et al., 1999; Hanson et al., 2010; Henriksen et al., 2008; Kolditz et al., 2012; Ledoux et al., 2007; Lemieux and Sudicky, 2010; Monteil, 2011; Park et al., 2009; Saleh et al., 2011; Scibek et al., 2007). In addition to these publications, many regional-scale models were developed with MODFLOW in the United States and China for integrated water management purposes (Rossman and Zlotnik, 2013; Zhou and Li, 2011). Except for Monteil (2011) and Pryet et al. (2014), none of these explicitly focus on distributed stream-aquifer exchanged water flux. Moreover, among DPBMs dedicated to stream-aquifer exchanges, only Monteil (2011) and Pryet et al. (2014) performed distributed estimations of streamaquifer exchanges at the regional scale. These applications exclusively use the conductance model, for which the longitudinal distribution of the conductance along the stream network has to be calibrated (Pryet et al., 2014).

The conductance model historically assumes vertical fluxes at the stream-aquifer interface (Krause et al., 2012a; Rushton and Tomlinson, 1979; Sophocleous, 2002). The hypothesis of vertical fluxes is discussed by Rushton (2007) based on numerical experiments that showed its limit. Indeed, at the regional scale, stream-aquifer exchanges seem to be more controlled by the horizontal permeability of the aquifer unit than by the equivalent vertical permeabilities of both the riverbed and the aquifer unit. Recently, this formulation of the conductance model proved to be suitable for the calibration of a regional modelling of stream-aquifer exchanges (Pryet et al., 2014). As formulated by Rushton (2007), Pryet et al. (2014) calibrated a correction factor $\left(F_{\text {cor }}\right)$ :

$Q=F_{\text {cor }} \times K_{\mathrm{h}} \times W \times\left(H_{\text {riv }}-H_{\mathrm{A}}^{*}\right)$,

where $Q\left[\mathrm{~m}^{3} \mathrm{~s}^{-1}\right]$ is the stream-aquifer flux, $H_{\text {riv }}$ and $H_{\mathrm{A}}^{*}$ $[\mathrm{m}]$ are the hydraulic heads in the river and the calculated piezometric head, respectively, and $W[\mathrm{~m}]$ the mesh size. The expression $F_{\text {cor }} \times K_{\mathrm{h}} \times W$ represents the conductance coefficient, $K_{\mathrm{h}}\left[\mathrm{m} \mathrm{s}^{-1}\right]$ is the aquifer horizontal permeability and $F_{\text {cor }}[-]$ an adjustable, lumped parameter called correction factor. 
This model defines the conductance parameter at the regional scale based on regional properties of the aquifer system. Even if it does not allow a proper simulation of water fluxes for disconnecting systems (Brunner et al., 2009a, b), it allows the simulation of disconnected systems using a maximum infiltrated flux (Pryet et al., 2014; Saleh et al., 2011). Indeed, stream-aquifer disconnection does not necessarily occur when the water table is beneath the clogging layer representing the streambed (as expressed in MODFLOW, Brunner et al. 2010), but when the pressure gradient in the unsaturated zone is negligible leading to a minimum pressure at the streambed interface and a constant stream to aquifer flux (Brunner et al., 2009a). To improve the assessment of the water flux through the unsaturated zone, which develops below the streambed in the case of a disconnected system, the maximal stream to aquifer flux could be defined as a function of both the streambed properties and the underlying regional aquifer properties. This implies to better understand the implications of heterogeneity and clogging processes in the streambed on disconnection (Brunner et al., 2011).

To provide accurate estimates, the conductance model has to be constrained by the piezometric head below the river and the surface water elevation. Former applications used a fixed water level throughout the simulation period (Arnold et al., 1999; Chung et al., 2010; Flipo et al., 2007b; Gomez et al., 2003; Ke, 2014; Kim et al., 2008; Monteil, 2011; Perkins and Sophocleous, 1999; Ramireddygari et al., 2000; Thierion et al., 2012). Saleh et al. (2011) showed that this methodology not only leads to biased assessments of streamaquifer exchanges, but also to biased estimates of the nearriver piezometric head distributions. In addition, Diem et al. (2014) recently showed that groundwater residence times are also strongly affected by the estimation of in-stream longitudinal water level distributions. These results are due to the fact that stream-aquifer exchange rates adapt very quickly to changes in surface water levels (Koussis et al., 2007; Maier and Howard, 2011; Rosenberry et al., 2013).

Consequently, the simulation of variable surface water levels is of primary importance for the estimation of distributed stream-aquifer exchanges along the stream network at the regional scale (Pryet et al., 2014; Saleh et al., 2011). Saleh et al. (2013) recommend the usage of local 1-D Saint-Venant based hydraulic models to build rating curves for every cell of a coarser regional model (Saleh et al., 2011) that uses simpler in-stream water routing models as RAPID (David et al., 2011). Such models are then coupled with the conductance model to simulate stream-aquifer exchanges at the regional scale along thousands of kilometres of river networks with a $1 \mathrm{~km}$ spatial discretisation (see for instance Pryet et al., 2014 for such an application along $3250 \mathrm{~km}$ of the Paris basin river network).

\subsection{Conceptual requirements at the continental scale}

Russell and Miller (1990) achieved the first global distributed runoff calculation based on a $4^{\circ} \times 5^{\circ}$ grid mesh coupled with a land surface model (LSM) and an atmospheric global circulation model (AGCM). It appears that even at this scale the river networks play an important role in the circulation models and water transfer time. Since then, few models have been developed to simulate the main river basins in the AGCMs with a grid mesh of $\sim 1^{\circ} \times 1^{\circ}$, which roughly corresponds to a $100 \mathrm{~km} \times 100 \mathrm{~km}$ resolution (Oki and Sud, 1998). geographical information systems (GISs) were used to derive the river networks from DEMs (Oki and Sud, 1998). Jointly RRMs (river routing models) have been developed with simple transfer approaches, assuming either a steady uniform water velocity at the global scale or a variable water velocity based on simple geomorphological laws and the Manning formula (Arora and Boer, 1999).

Decharme and Douville (2007) implemented the approach with a constant in-river water velocity (assumed to be $0.5 \mathrm{~m} \mathrm{~s}^{-1}$ ) within the LSM, today referred to as SURFEX (Masson et al., 2013). Step by step, the description of streamaquifer exchanges was improved by:

- The introduction of a variable in-river water velocity (Decharme et al., 2008).

- A transfer time delay due to the stream-aquifer interface (Decharme et al., 2012).

- The explicit simulation with a DPBM of the worldwide largest aquifer systems coupled with the explicit simulation of the river networks draining surface basins larger than $50000-100000 \mathrm{~km}^{2}$ (Vergnes and Decharme, 2012).

- The explicit simulation of stream-aquifer exchanges based on the conductance model on a $0.5^{\circ} \times 0.5^{\circ}$ grid mesh (Vergnes et al., 2012; Vergnes and Decharme, 2012) in agreement with the continental scale transfer time delay of 30 days introduced by Decharme et al. (2012).

As expected given the numerical experiments of Maxwell and Miller (2005), accounting for groundwater kinetics improves the global hydrological mass balance (Decharme et al., 2010; Alkama et al., 2010; Yeh and Eltahir, 2005). Although the explicit simulation of stream-aquifer exchanges with the conductance model slightly improves the models' performances in terms of spatio-temporal discharge and real evapotranspiration assessments (Vergnes et al., 2012; Vergnes and Decharme, 2012), the global calibration of the conductance parameter has to take into account the multi-scale structure of the stream-aquifer interfaces. This means that a better assessment, not only of simple DEMderived river networks, but also of the transfer time in the stream-aquifer interfaces is required, as well as the sub grid 
definition of dendritic river networks. Coupled with proper scaling procedures (see next section) these approaches seem to be less computationally demanding than the one proposed by Wood et al. (2011) and slightly less overparameterised, which should make it possible to better solve the estimation of stream-aquifer exchanges at the continental scale.

\subsection{Up- and downscaling stream-aquifer exchanges}

At the regional scale, most of the hydrogeological models are limited in taking into account local processes such as the effect of near-river pumping, or storage in the hyporheic zone, because they require a very fine spatial discretisation, which can be incompatible with the resolution of the model or, which drastically decreases the efficiency of the model. Also, the use of regional models for solving local issues, as well as the reverse, leads to equifinality problems (Beven, 1989; Beven et al., 2011; Ebel and Loague, 2006; Klemes, 1983; Polus et al., 2011), boundary condition inconsistencies (Noto et al., 2008), or computational burdens (Jolly and Rassam, 2009). The use of local models for solving regional issues entails the same effects (Aral and Gunduz, 2003, 2006; Wondzell et al., 2009). Therefore, alternative ways of modelling are needed to simulate the behaviour of stream-aquifer interfaces at the regional scale properly (Werner et al., 2006), especially as, for a given reach of river, the direction of stream-aquifer exchanges can vary longitudinally (Bencala et al., 2011). The concept of nested stream-aquifer interface led to the identification of the river network, and by extension the hyporheic corridor, as the location where to scale models for the accurate simulation of hydrological processes (Sect. 2.6). On the one hand, regional surface-subsurface models allow the simulation of the hyporheic corridor and the regional aquifer. On the other hand, intermediate-scale models permit the simulation of hydrological spiralling. It therefore seems relevant to explicitly simulate the alluvial plains in a regional model, either with an explicit layer in pseudo 3-D models as MODFLOW, or with specific parameters for 3-D models based on Richards equations (Sect. 3.1). In this way, regional and intermediate models can be configured in a nested setup, allowing the identification of model parameters using the regional model for large-scale geological heterogeneities and the intermediate-scale model for the smaller alluvial plain heterogeneities. This setup is in agreement with the nested heterogeneities defined by Refsgaard et al. (2012). The coupling between a regional-scale model and an intermediate-scale model of the alluvial plain requires ensuring the conservation of the mass between the two models. An iterative procedure is developed to achieve this objective (Fig. 2). At each iteration $j$, the procedure consists of:

1. Run the regional model.

2. Define the boundary conditions of the intermediate model with the outputs of the regional model.
3. Downscale the regional piezometric head distribution.

4. Run the intermediate model.

5. Upscale the conductance parameter at the regional scale.

The final objective of the procedure is to equalise the stream-aquifer exchanges estimated at both the regional and the intermediate scales. A prerequisite for the application of this iterative procedure is the definition of the conductance parameter at the intermediate scale.

\subsubsection{The conductance model at the intermediate scale}

To scale the conductance model at the regional scale properly, the correction factor, $F_{\text {cor }}$ in Eq. (1), must be defined at the intermediate scale analytically. The conductance model historically assumes vertical fluxes at the stream-aquifer interface (Krause et al., 2012a; Rushton and Tomlinson, 1979; Sophocleous, 2002), so that it seems to be a proper framework for determining up- and downscaling properties of stream-aquifer interfaces (Boano et al., 2009; Engdahl et al., 2010). However, this hypothesis becomes less valid for a coarse grid mesh (Mehl and Hill, 2010; Rushton, 2007). In such a case, Brunner et al. (2010) point out that the calculated piezometric head at the stream-aquifer interface does not represent the piezometric head in the hyporheic zone, but the near-stream aquifer piezometric head (Fig. 3). This is due to the fact that state variables are discrete values associated with an area by an averaging over the cell (finite differences and finite volumes), or over the surface around the node (finite elements). Stream-aquifer exchanges are then calculated across a surface, which encompasses the river. As a consequence, the averaging induces uncertainties in the assessment of head below the river. The conductance parameter hence is scale dependent (Vermeulen et al., 2006). Morel-Seytoux (2009) proposed to relate the exchange flux to the near-river piezometric head, $h_{\mathrm{c}}$, (Eq. 2), for which it can be assumed that the distance, $d$, from the river is long enough to reach the validity domain of the Dupuit-Forchheimer approximation. Using the mass conservation between the local flux at the interface and the regional flux, Morel-Seytoux (2009) expresses the flux as follows:

$$
\begin{aligned}
Q & =k_{i} w \frac{1}{\frac{1}{\alpha R_{\mathrm{w}} k_{\mathrm{sb}}}\left[\left(2 \alpha k_{i}-k_{\mathrm{sb}}\right) e_{\mathrm{sb}}+k_{\mathrm{sb}} e_{\mathrm{aq}}\right]+\frac{d}{e_{\mathrm{aq}}}} \\
& \times\left(h_{\mathrm{riv}}-h_{\mathrm{c}}\right),
\end{aligned}
$$

where $k_{i}$ and $k_{\mathrm{sb}}\left[\mathrm{m} \mathrm{s}^{-1}\right]$ are the horizontal aquifer permeability and vertical streambed permeability, respectively; $e_{\mathrm{aq}}$ and $e_{\mathrm{sb}}[\mathrm{m}]$ are the aquifer and streambed thicknesses; $\alpha[-]$ is the aquifer anisotropy factor; $R_{\mathrm{w}}[\mathrm{m}]$ is the river width; $w$ the intermediate mesh size.

Citing Bouwer (1969) and Haitjema (1987), MorelSeytoux (2009) indicates that $d$ ranges between twice the 


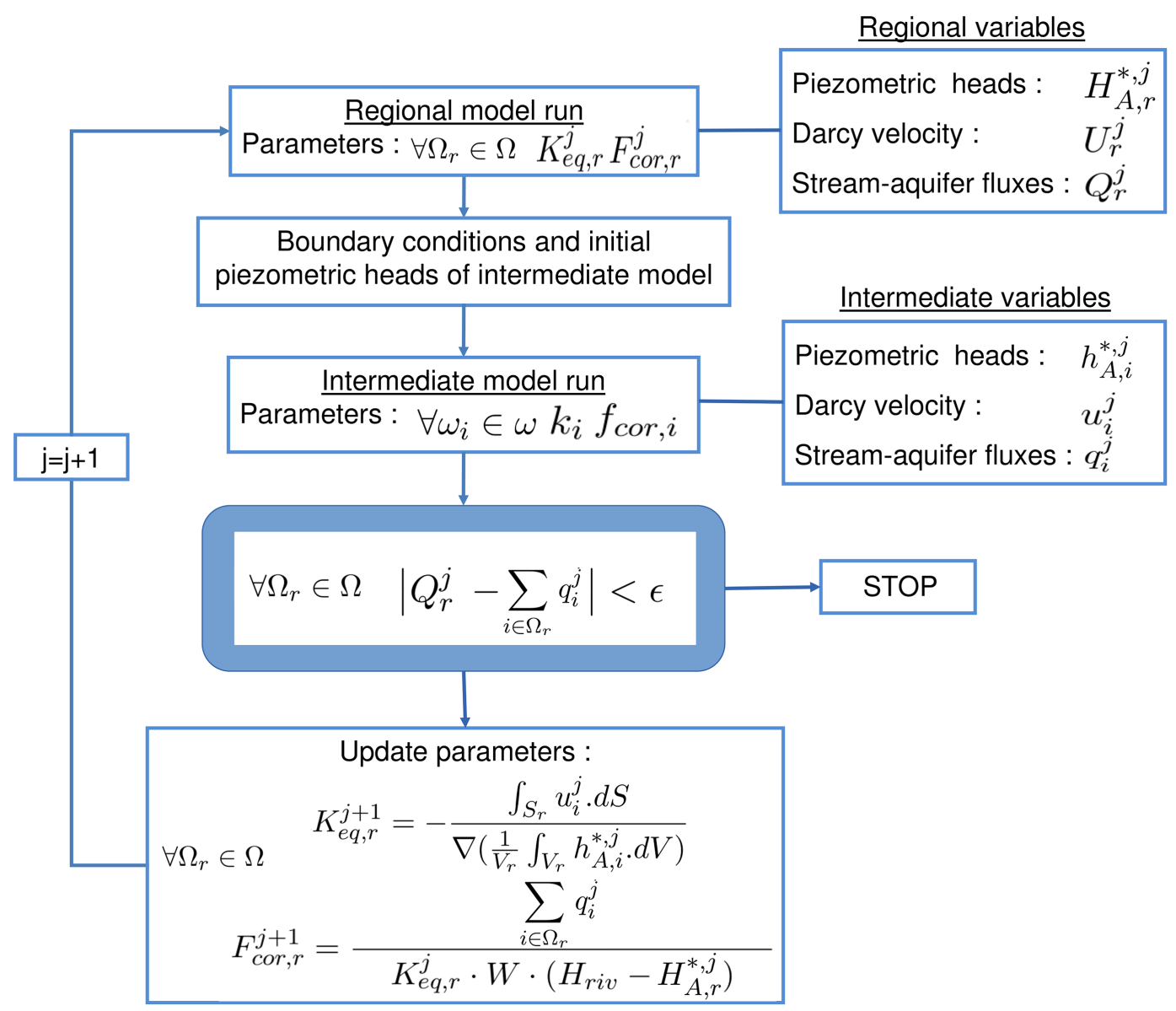

Figure 2. Iterative modelling framework for coupling regional and intermediate scales. $\mathrm{r}$ and $\mathrm{i}$ indices are related to regional and intermediate scales, respectively. Capital letters represent regional parameters and variables, while lowercase letters refer to intermediate ones. $\Omega$ is the regional mesh divided in $r \times \Omega_{\mathrm{r}}$ subdomains, $\Omega_{\mathrm{r}}$ being a regional cell. In the same way, $\omega$ is the intermediate model domain divided in $i \times \omega_{\mathrm{i}}$ subdomains, $\omega_{\mathrm{i}}$ being an intermediate cell. $f_{\text {cor }}$ is the conductance correcting factor to upscale and $k$ the horizontal permeability on which $K_{\text {eq }}$ is based. $S_{\mathrm{r}}$ and $V_{\mathrm{r}}$ are the cross section and volume of $\Omega_{\mathrm{r}}$, and $\nabla$ denotes the head gradient.

thickness of the underlying aquifer unit and ten times the river width. This formulation thus refers to the intermediate scale, where the cell sizes have to be adapted to $d$ and to the averaging of the piezometric head to ensure that the cell head value $h_{\mathrm{A}}^{*}$ corresponds to $h_{\mathrm{c}}$.

Assuming that $h_{\mathrm{c}} \approx h_{\mathrm{A}}^{*}$, which can be substituted in Eq. (2), the correcting factor becomes dependent on the mesh size, $w$ :

$f_{\mathrm{cor}}(w)=\frac{1}{\frac{1}{\alpha R_{\mathrm{w}} k_{\mathrm{sb}}}\left[\left(2 \alpha k_{i}-k_{\mathrm{sb}}\right) e_{\mathrm{sb}}+k_{\mathrm{sb}} e_{\mathrm{aq}}\right]+\frac{f(w)}{e_{\mathrm{aq}}}}$,

where $f$ denotes the mathematical scaling function of the $i$ th cell size, which links $d$ and $w$. Under simplifying assumptions, $f$ may be a linear function (Bouwer, 1969; Haitjema, 1987). A proper simulation of stream-aquifer exchanges therefore implies an adaptive mesh to scale the river cells to the river network from small upstream tributaries to large downstream rivers. The mesh can be derived from a DEM, which is a source of uncertainties for the assessment of stream-aquifer exchanges (Käser et al., 2014).

\subsubsection{Downscaling the piezometric head}

The downscaling procedure is adapted from Chen and Durlofsky (2006) and Mehl and Hill (2002). Assuming that the regional discharge is homogeneously distributed along the regional cells border, the intermediate piezometric head can be linearly interpolated based on the local properties of the cell coupled with the regional gradient:

$h_{n}=h_{1}+\frac{K_{\text {eq }}}{k_{\text {eq }, n}} \frac{x_{n}-X_{1}}{X_{2}-X_{1}}\left(H_{2}-H_{1}\right), X_{1} \leq x_{n} \leq X_{2}$,

where $X$ denotes the coordinate of the regional mesh, and $x$ the one of the intermediate one. $K_{\text {eq }}\left[\mathrm{m} \mathrm{s}^{-1}\right]$ is the regional equivalent permeability, $k_{\text {eq, } n}$ the equivalent permeability of the $n$ intermediate cells between $X_{1}$ and $x_{n} . H_{n}$ [m] is the regional piezometric head at point $X_{n}$, and $h_{n}$ 


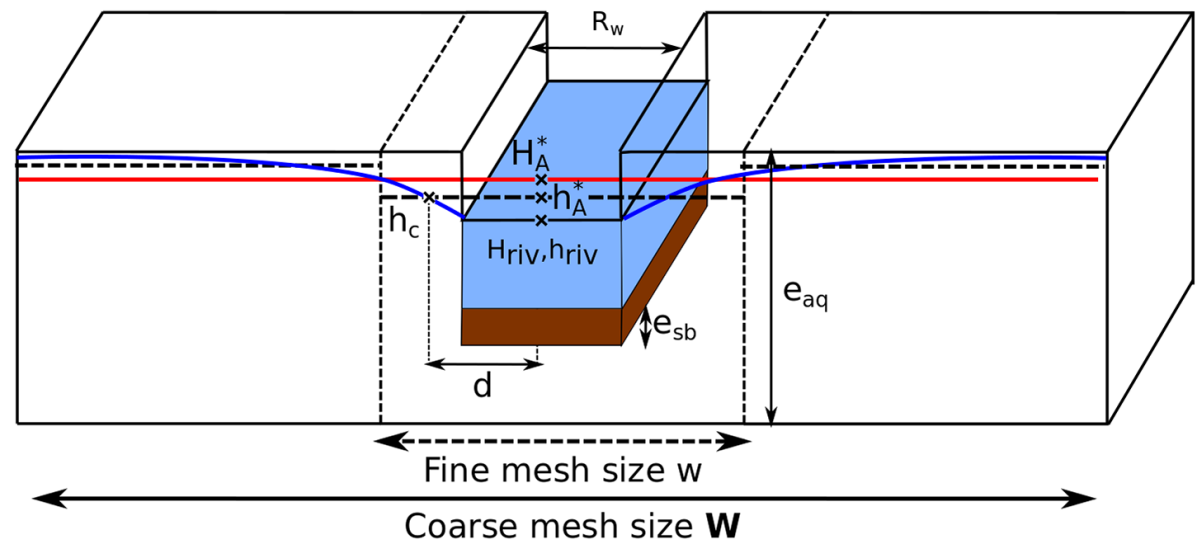

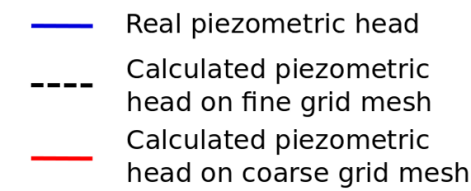

Figure 3. Scaling effects on averaged near-river piezometric heads.

[m] the intermediate piezometric heads at point $x_{n}$. Assuming that $h_{1}=H_{1}$, the local piezometric head at point $x_{n}$ becomes a function of regional heads. However, due to the assumptions, the downscaling procedure becomes less accurate when the dimensional difference between regional and intermediate mesh grid is high $(W \gg w)$.

\subsubsection{Upscaling the conductance at the regional scale}

While methodologies for the upscaling of permeability distributions already exist (Renard, 1997), it remains unclear how to upscale the conductance parameter. In order to study the scaling effects on $F_{\text {cor }}$ (see Eq. 1) an iterative modelling procedure is proposed (Fig. 2). At iteration $j$, the consistency of fluxes between scales is defined as follows:

$Q_{\mathrm{r}}^{j}=\sum_{i \in \Omega_{\mathrm{r}}} q_{i}^{j}$,

where $i$ denotes the intermediate cells, $\Omega_{\mathrm{r}}$ a regional cell, $Q_{\mathrm{r}}^{j+1}$ the regional stream-aquifer flow resulting from the upscaling of iteration $j$ and $q_{i}^{j}$ the intermediate stream-aquifer flow at iteration $j$. For $\left|Q_{\mathrm{r}}^{j+1}-Q_{\mathrm{r}}^{j}\right|<\epsilon$, the procedure converges, $\epsilon$ being the convergence criterion. Otherwise, new regional conductance values are calculated using Eq. (5):

$\forall \Omega_{\mathrm{r}} \in \Omega, F_{\mathrm{cor}, \mathrm{r}}^{j+1}=\frac{\sum_{i \in \Omega_{\mathrm{r}}} q_{i}}{K_{\mathrm{eq}, \mathrm{r}}^{j} \cdot W \cdot\left(H_{\mathrm{riv}, \mathrm{r}}-H_{\mathrm{r}}^{*, j}\right)}$,

where $\Omega$ is the regional mesh, $\Omega_{\mathrm{r}}$ the $r$ th regional cell, $K_{\text {eq,r }}^{j}$ $\left[\mathrm{m}^{3} \mathrm{~s}^{-1}\right]$ the estimated equivalent permeability of the $r$ th cell at iteration $j, W[\mathrm{~m}]$ the mesh size, $H_{\text {riv, } \mathrm{r}}$ and $H_{\mathrm{r}}^{*, j}[\mathrm{~m}]$ the
Stream

Stream-bed river and piezometric heads of the $r$ th cell at the $j$ th iteration. The equivalent permeability can be updated as follows:

$\forall \Omega_{\mathrm{r}} \in \Omega, K_{\mathrm{eq}, \mathrm{r}}^{j+1}=-\frac{\int_{S_{\mathrm{r}}} u_{i}^{j} \mathrm{~d} S}{\nabla\left(\frac{1}{V_{\mathrm{r}}} \int_{V_{\mathrm{r}}} h_{i}^{*, j} \mathrm{~d} V\right)}$

where $S_{\mathrm{r}}$ and $V_{\mathrm{r}}$ are the cross section and volume of the $r$ th regional cell, and $\nabla$ denotes the gradient.

The study of the evolution of both $F_{\text {cor }}$ and permeabilities under various hydrological conditions should be very informative concerning the feasibility of the conductance parameter scaling laws.

\section{The MIM methodology: from concepts to practice}

The methodology of Mouhri et al. (2013) is hereby graphically developed, scaling in space the three pools of methods (measurements-interpolation-modelling) needed to fully understand stream-aquifer interfaces at various scales. The outcome is the MIM methodological tool, which localises in space the type of stream-aquifer interface that can be studied by a given approach (see the five scales of interest in Fig. 4: local, intermediate (or reach), watershed, regional and continental scales). From Fig. 5, it clearly appears that a better understanding of the functioning of nested stream-aquifer interfaces relies on the combination of models, in situ networks, space borne data and interpolation techniques. MIM has the ability to clearly display the representativeness of a specific research within a holistic framework dedicated to the study of nested stream-aquifer interactions at all scales. It is 


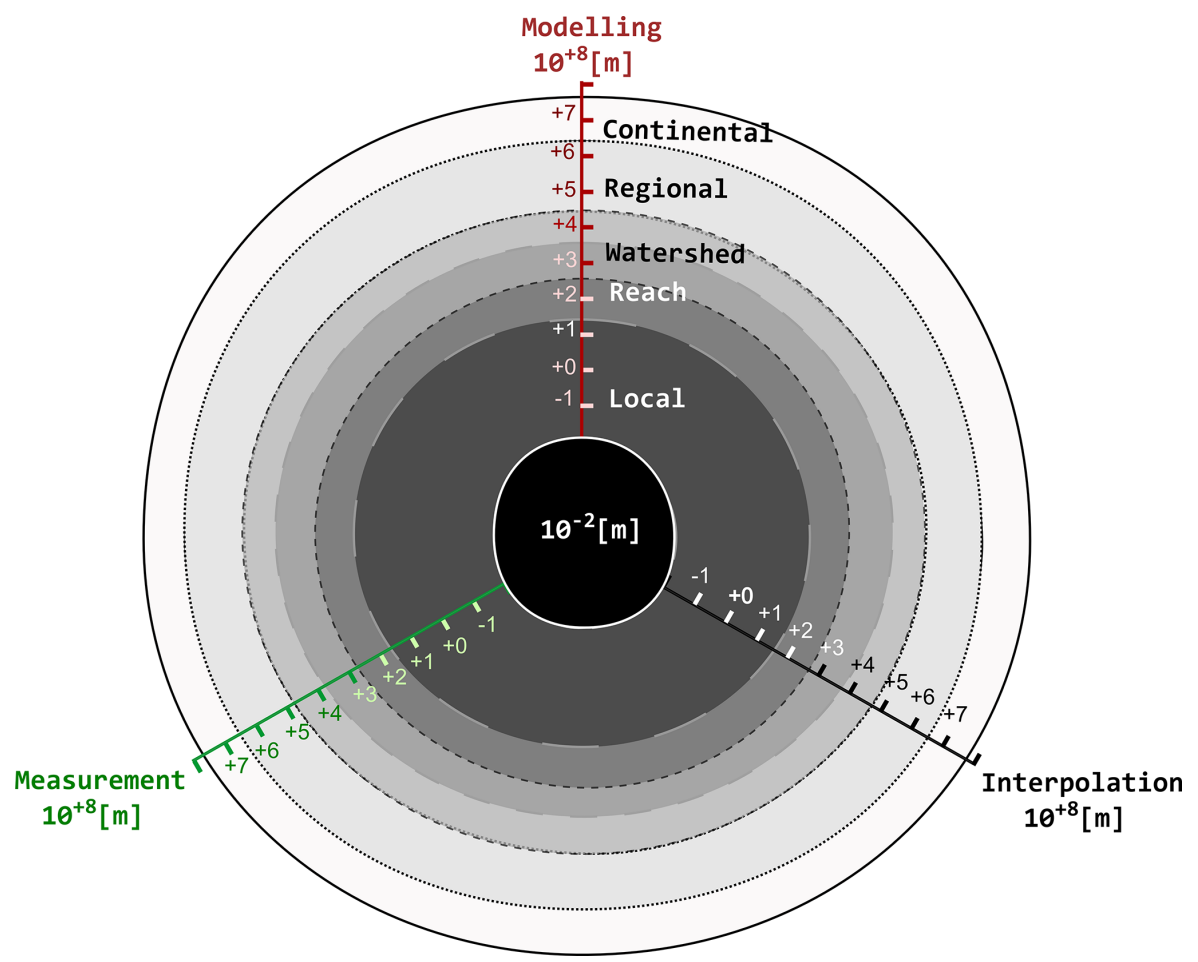

Figure 4. MIM methodological space. Axis in logarithmic scale.

a valuable tool for the definition of combined field measurements and modelling approaches. It permits the determination of the dimension of the objects that need to be studied to scale processes. This is illustrated in Sect. 4.1, where the size of a river reach relevant for testing up- and downscaling strategies is identified. Space borne data coupled with models can also be displayed in the MIM space (Sect. 4.2), without identifying methodologies to scale processes from the watershed to the regional and continental scales (Sect. 4.3).

\subsection{Coupled in situ modelling approaches: from local to watershed scale}

Figure 5 displays the types of stream-aquifer interfaces that can be studied by the multi-scale sampling system developed by Mouhri et al. (2013), based on LOcal MOnitoring Stations (LOMOS) distributed along a $6 \mathrm{~km}$-river network covering a $40 \mathrm{~km}^{2}$ watershed. As illustrated in Fig. 5, a single LOMOS allows the monitoring, based on water pressure and temperature measurements, of stream cross sections ranging from $0.1-\sim 10 \mathrm{~m}$. LOMOS data are used with coupled thermo-hydro models to determine the properties of the aquifer units and the river beds (Mouhri et al., 2013), which can be used to assess the value of the conductance at the watershed scale (Mehl and Hill, 2002; Morel-Seytoux, 2009; Vermeulen et al., 2006; Rushton, 2007). Assuming that it is possible to distribute multiple LOMOS data, and the associated conductance values, along a stream network (for instance using FO-DTS - Fibre Optic Distributed Thermal Sensors), local in situ data become the basis of a broader surface-subsurface modelling at the watershed scale. The upscaling is hence structured around stream cross sections of $\sim 1-10 \mathrm{~m}$ with a representative reach length in the order of magnitude of 10-100 m (Fig. 5). The next experiment, aiming at determining the upscaling law for the conductance coefficient at the watershed scale, will thus be designed based on the specificities of a river stretch at this scale (i.e. the study of a riffle-pool sequence). In this specific case, the spatial rationale behind the new experiment is an outcome of the MIM analysis, which defines the size of the objects to be studied. Identifying the size of the objects of interest also provides guidance for the determination of a relevant mesh size, which in return imposes locations where interpolations need to be performed.

\subsection{Space borne approaches: regional and continental scales}

Current and future satellite data are used to observe the continental water cycle and better constrain LSM (Sect. 3.5). They are thus located at the continental and regional scales on the measurement axis of the MIM space (Fig. 5). Downscaling methods are also being developed to refine current coarse optical imagery into finer resolution products, or to average data over a spatial object (for instance a river reach) to improve their accuracy (Aires et al., 2013). These methods are 


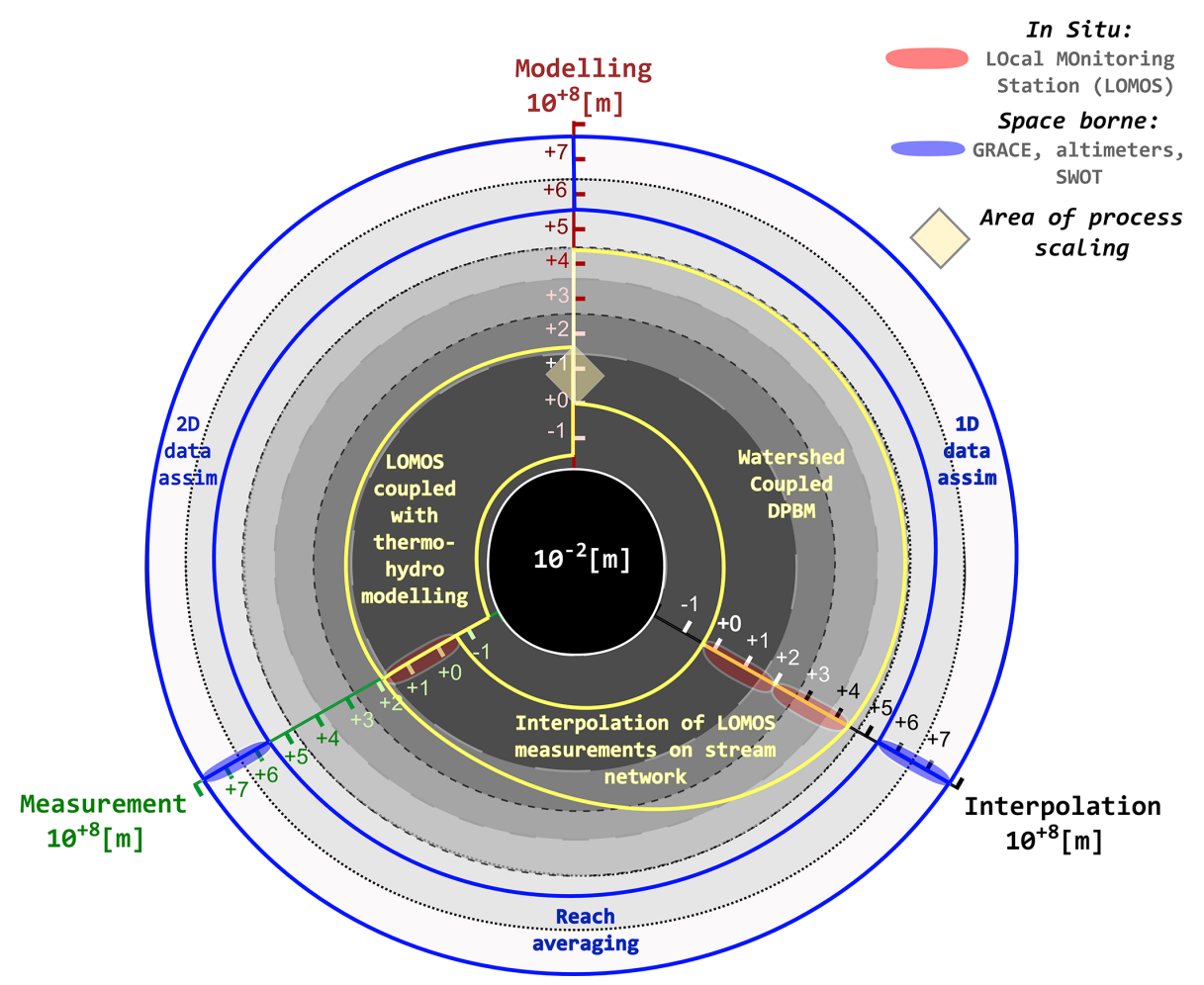

Figure 5. Localisation of two approaches in the MIM methodological space. In yellow: upscaling methodology from the local to the watershed scale based on LOMOS coupled with DPBM. In blue: regional to continental scales covered by satellite data coupled to assimilation frameworks. Axis in logarithmic scale. data assim: data assimilation.

indicated on the interpolation axis in Fig. 5. Measurements and interpolated data can both be used in data assimilation frameworks.

Some attempts have been undertaken to force or assimilate satellite-based observations of different components of the water cycle to improve LSM water budget and river routing schemes: over the Mississippi Basin (Zaitchik et al., 2008), the Arkansas River Basin (Pan et al., 2008), the Amazon Basin (Getirana et al., 2013), the Brahmaputra River (Michailovsky et al., 2013), and over 10 large river basins widely spread in latitude (Sahoo et al., 2011). Further, Andreadis et al. (2007), Durand et al. (2008) and Biancamaria et al. (2011) have developed different assimilation schemes to correct hydrodynamic model parameters and variables using virtual SWOT observations. They have shown the potential of this new kind of spatially distributed data set to better constrain hydraulic models.

As stream-aquifer exchanges are very responsive to inriver water level fluctuations (Diem et al., 2014; Koussis et al., 2007; Maier and Howard, 2011; Saleh et al., 2011), the assimilation of space borne data and data products in numerical models, like the ones used by Pryet et al. (2014), Saleh et al. (2011) and Vergnes and Decharme (2012) (Fig. 5), should enable a better understanding of stream-aquifer interaction at very large scale.

\subsection{Further challenges}

Albeit being a breakthrough in terms of surface coverage, SWOT requirements impose restrictions on observable stream-aquifer interfaces, which can be visualised in the MIM space (Fig. 5). As SWOT will provide information for basins on average larger than $50000 \mathrm{~km}^{2}$ (Sect. 2.5), it appears in the MIM space that SWOT applications do not completely overlap other methodologies as the one previously proposed to scale processes between the local and the watershed scales. To overcome this issue, a projected airborne campaign, called AirSWOT, with a main payload similar to the one of SWOT, but with a higher spatial resolution (metric), will (i) help to determine whether regular airborne campaigns can provide a valuable tool to connect the watershed scale to the regional/continental one with the help of multiscale modelling tools (see Sect. 3.6) and (ii) make it possible to design new in situ monitoring stations derived from the LOMOS defined by Mouhri et al. (2013) but dedicated to the watershed/regional scale, which means for river cross sections larger than a few decametres, with a water depth of a few metres. 


\section{Conclusions}

Based on a systemic approach of hydrosystems, we propose to consider the stream-aquifer interface as a cascade of nested objects. These nested objects depend on the scale of interest. At the watershed, regional and continental scales, they consist of alluvial plains, while within the alluvial plain itself (intermediate-reach scale), they consist of hyporheic corridors including riparian zones. Within the riparian zone (local scale), they consist of HZ, and so on until the water column-benthos interface within the river itself.

Estimating stream-aquifer exchanges therefore requires combination of the modelling of various processes with different characteristic times. Stakeholders need more detailed information at the regional scale, as it is the water resources management scale. However, depending on the desired refinement of the modelling at the regional scale (i.e. number of processes taken into account), the estimation of streamaquifer exchanges may vary significantly. It is thus crucial to develop modelling tools which can precisely simulate stream-aquifer exchanges at the reach scale within a regional basin. These innovative modelling tools should be multiscale modelling platforms, which implement the concept of nested stream-aquifer interfaces as the core of the coupling between regional and intermediate scale models: the former simulating the basin, the latter the alluvial plains. To achieve this, it was shown that process scaling should be performed around the river network.

To fully estimate stream-aquifer exchanges, this multiscale modelling tool has to be coupled with observation devices. The MIM methodology provides a powerful framework to jointly develop observation infrastructures and modelling tools, allowing the localisation of the global structure in the scale space. Although the scaling of processes was identified around the reach scale from the local to the watershed scale, airborne campaigns, as well as regional in situ systems, will have to be rationalised to connect the watershed to the regional and continental scales, which can be observed with a large diversity of satellite instruments.

Acknowledgements. This research is funded by CNES TOSCA SWOT project, the ONEMA NAPROM project, and structured within the "Stream-Aquifer Interfaces" workpackage of the PIREN Seine research programme. We kindly thank Angela Armakola for revising the English version of the paper, as well as the two anonymous reviewers for their fruitful comments, which helped improve the paper significantly.

Edited by: Y. Fan

\section{References}

Abbott, M., Bathurst, J., Cunge, J., O’Connell, P., and Rasmussen, J.: An introduction to the European Hydrological System, 1. History and philosophy of a physically based distributed modelling system, J. Hydrol., 87, 45-59, 1986.

Abu-El-Sha's, W. and Rihani, J.: Application of the high performance computing techniques of parflow simulator to model groundwater flow at Azraq basin, Water Resour. Manage., 21, 409-425, doi:10.1007/s11269-006-9023-5, 2007.

Aires, F., Prigent, C., Papa, F., and Cretaux, J.-F.: Downscaling of the inundation extent over the Niger delta using a combination of multi-wavelength and Modis retrievals, J. Hydrometeorol., doi:10.1175/JHM-D-13-032.1, 2013.

Alkama, R., Decharme, B., Douville, H., Becker, M., Cazenave, A., Sheffield, J., Voldoire, A., Tyteca, S., and Moigne, P. L.: Global Evaluation of the ISBA-TRIP Continental Hydrological System, Part I: Comparison to GRACE Terrestrial Water Storage Estimates and In Situ River Discharges, J. Hydometeorol., 11, 583600, 2010.

Allen, J.: The classification of cross-stratified units, with notes on their origin, Sedimentology, 2, 93-114, doi:10.1111/j.13653091.1963.tb01204.x, 1963

Allen, J.: On bed forms and palaeocurrents, Sedimentology, 6, 153190, doi:10.1111/j.1365-3091.1966.tb01576.x, 1966.

Andersen, J., Refsgaard, J., and Jensen, K.: Distributed hydrological modelling of the Senegal River Basin - model construction and validation, J. Hydrol., 247, 200-214, 2001.

Anderson, M. P.: Heat as a Ground Water Tracer, Ground Water, 43, 951-968, doi:10.1111/j.1745-6584.2005.00052.x, 2005.

Anderson, M. P., Aiken, J. S., Webb, E. K., and Mickelson, D. M.: Sedimentology and hydrogeology of two braided stream deposits, Sediment. Geol., 129, 187-199, doi:10.1016/S00370738(99)00015-9, 1999.

Anderson, W. P., Storniolo, R. E., and Rice, J. S.: Bank thermal storage as a sink of temperature surges in urbanized streams, J. Hydrol., 409, 525-537, doi:10.1016/j.jhydrol.2011.08.059, 2011.

Andreadis, K., Clark, E., Lettermaier, D., and Alsdorf, D.: Prospects for river discharge and depth estimation through assimilation of swath-altimetry into a raster-based hydrodynamics model, Geophys. Res. Lett., 34, L10403, doi:10.1029/2007GL029721, 2007.

Andreadis, K., Schumann, G., and Pavelsky, T.: A simple global river bankfull width and depth database, Water Resour. Res., 49, 7164-7168, doi:10.1002/wrcr.20440, 2013.

Anibas, C., Fleckenstein, J., Volze, N., Buis, K., Verhoeven, R., Meire, P., and Batelaan, O.: Transient or steady-state? Using vertical temperature profiles to quantify groundwatersurface water exchange, Hydrol. Process., 23, 2165-2177, doi:10.1002/hyp.7289, 2009.

Anibas, C., Verbeiren, B., Buis, K., Chorman'ski, J., De Doncker, L., Okruszko, T., Meire, P., and Batelaan, O.: A hierarchical approach on groundwater-surface water interaction in wetlands along the upper Biebrza River, Poland, Hydrol. Earth Syst. Sci., 16, 2329-2346, doi:10.5194/hess-16-2329-2012, 2012.

Aral, M. and Gunduz, O.: Scale effects in large scale watershed modeling, in: International Conference on Water and Environment, edited by: Singh, V. and Yadava, R., Allied Publishers, India, 37-51, 2003. 
Aral, M. and Gunduz, O.: Watershed Models, in: chap. Large-Scale Hybrid Watershed Modeling, Taylor \& Francis, Kentucky, USA, 75-95, 2006.

Arnold, J., Srinivasan, R., Muttiah, R., and Allen, P.: Continental scale simulation of the hydrologic balance, J. Am. Water Resour. Assoc., 35, 1037-1051, 1999.

Arora, V. and Boer, G.: A variable velocity flow routing algorithm for GCMs, J. Geophys. Res., 104, 30965-30979, 1999.

Bardini, L., Boano, F., Cardenas, M., Revelli, R., and Ridolfi, L.: Nutrient cycling in bedform induced hyporheic zones, Geochim. Cosmochim. Acta, 84, 47-61, doi:10.1016/j.gca.2012.01.025, 2012

Bauer, P., Gumbricht, T., and Kinzelbach, W.: A regional coupled surface water/groundwater model of the Okavango Delta, Botswana, Water Resour. Res., 42, W04403, doi:10.1029/2005WR004234, 2006.

Becker, M., Georgian, T., Ambrose, H., Siniscalchi, J., and Fredrick, K.: Estimating flow and flux of ground water discharge using water temperature and velocity, J. Hydrol., 296, 221-233, doi:10.1016/j.jhydrol.2004.03.025, 2004.

Bencala, K., Gooseff, M., and Kimball, B.: Rethinking hyporheic flow and transient storage to advance understanding of streamcatchment connections, Water Resour. Res., 47, W00H03, doi:10.1029/2010WR010066, 2011.

Bendjoudi, H., Weng, P., Guérin, R., and Pastre, J.: Riparian wetlands of the middle reach of the Seine river (France): historical development, investigation and present hydrologic functioning. A case study, J. Hydrol., 263, 131-155, 2002.

Bertrand, G., Goldscheider, N., Gobat, J.-M., and Hunkeler, D.: Review: From multi-scale conceptualization to a classification system for inland groundwater-dependent ecosystems, Hydrogeol. J., 20, 5-25, doi:10.1007/s10040-011-0791-5, 2012.

Beven, K.: Changing ideas in hydrology. The case of physicallybased model, J. Hydrol., 105, 157-172, 1989.

Beven, K., Smith, P. J., and Wood, A.: On the colour and spin of epistemic error (and what we might do about it), Hydrol. Earth Syst. Sci., 15, 3123-3133, doi:10.5194/hess-15-31232011, 2011.

Biancamaria, S., Andreadis, K., Durand, M., Clark, E., Rodriguez, E., Mognard, N., Alsdorf, D., Lettenmaier, D., and Oudin, Y.: Preliminary characterization of SWOT hydrology error budget and global capabilities, IEEE J. Sel. Top. Appl. Earth Observ. Rem. S., 3, 6-19, doi:10.1109/JSTARS.2009.2034614, 2010.

Biancamaria, S., Durand, M., Andreadis, K., Bates, P., Boone, A., Mognard, N., Rodríguez, E., Alsdorf, D., Lettenmaier, D., and Clark, E.: Assimilation of virtual wide swath altimetry to improve Arctic river modeling, Remote Sens. Environ., 115, 373381, 2011.

Billen, G. and Garnier, J.: Nitrogen transfers through the Seine drainage network: a budget based on the application of the 'Riverstrahler' model, Hydrobiologia, 410, 139-150, 2000.

Bixio, A., Gambolati, G., Paniconi, C., Putti, M., Shestopalov, V., Bublias, V., Bohuslavsky, A., Kasteltseva, N., and Rudenko, Y.: Modeling groundwater-surface water interactions including effects of morphogenetic depressions in the Chernobyl exclusion zone, Environ. Geol., 42, 162-177, doi:10.1007/s00254001-0486-7, 2002.

Blöschl, G. and Sivapalan, M.: Scale issues in hydrological modelling: A review, Hydrol. Process., 9, 251-290, 1995.
Boano, F., Camporeale, C., Revelli, R., and Ridolfi, L.: Sinuositydriven hyporheic exchange in meandering rivers, Geophys. Res. Lett., 33, L18406, doi:10.1029/2006GL027630, 2006.

Boano, F., Revelli, R., and Ridolfi, L.: Quantifying the impact of groundwater discharge on the surface-subsurface exchange, Hydrol. Process., 23, 2108-2116, doi:10.1002/hyp.7278, 2009.

Boano, F., Camporeale, C., and Revelli, R.: A linear model for coupled surface-subsurface flow in meandering stream, Water Resour. Res., 46, W07535, doi:10.1029/2009WR008317, 2010a.

Boano, F., Demaria, A., Revelli, R., and Ridolfi, L.: Biogeochemical zonation due to intrameander hyporheic flow, Water Resour. Res., 46, W02511, doi:10.1029/2008WR007583, 2010 b.

Bouwer, H.: Theory of seepage from open channels, in: vol. 5 of Advances in Hydroscience, Academic Press, New York, 1969.

Bridge, J. and Best, J.: Preservation of planar laminae due to migration of low-relief bed waves over aggrading upper-stage plane beds: comparison of experimental data with theory, Sedimentology, 44, 253-262, 1997.

Bridge, J. S.: Fluvial facies models: Recent developments, in: chap. Facies models revisited, Special Publication 84, SEPM, 85-170, 2006.

Bristow, C., S. and Best, J., L.: Braided rivers: perspectives and problems, Special Publications, Geological Society, London, 75, 1-11, doi:10.1144/GSL.SP.1993.075.01.01, 1993.

Brunke, M. and Gonser, T.: The ecological significance of exchange processes between rivers and groundwater, Freshwater Biol., 37 , 1-33, doi:10.1046/j.1365-2427.1997.00143.x, 1997.

Brunner, P., Li, H., Kinzelbach, W., Li, W., and Dong, X.: Extracting phreatic evaporation from remotely sensed maps of evapotranspiration, Water Resour. Res., 44, W08428, doi:10.1029/2007WR006063, 2008.

Brunner, P., Cook, P., and Simmons, C.: Hydrogeologic controls on disconnection between surface water and groundwater, Water Resour. Res., 45, W01422, doi:10.1029/2008WR006953, 2009a.

Brunner, P., Simmons, C., and Cook, P.: Spatial and temporal aspects of the transition from connection to disconnection between rivers, lakes and groundwater, J. Hydrol., 376, 159-169, doi:10.1016/j.jhydrol.2009.07.023, 2009b.

Brunner, P., Simmons, C., Cook, P., and Therrien, R.: Modeling Surface Water-Groundwater Interaction with MODFLOW: Some Considerations, Ground Water, 48, 174-180, doi:10.1111/j.1745-6584.2009.00644.x, 2010.

Brunner, P., Cook, P., and Simmons, C.: Disconnected Surface Water and Groundwater: From Theory to Practice, Ground Water, 49, 460-467, doi:10.1111/j.1745-6584.2010.00752.x, 2011.

Burkholder, B. K., Grant, G. E., Haggerty, R., Khangaonkar, T., and Wampler, P. J.: Influence of hyporheic flow and geomorphology on temperature of a large, gravel-bed river, Clackamas River, Oregon, USA, Hydrol. Process., 22, 941-953, doi:10.1002/hyp.6984, 2008.

Burt, T.: A third paradox in catchment hydrology and biogeochemistry: decoupling in the riparian zone, Hydrol. Process., 19, 2087-2089, doi:10.1002/hyp.5904, 2005.

Burt, T., Pinay, G., Matheson, F., Haycock, N., Butturini, A., Clement, J., Danielescu, S., Dowrick, D., Hefting, M., HillbrichtIlkowska, A., and Maitre, V.: Water table fluctuations in the riparian zone: comparative results from a pan-European experiment, J. Hydrol., 265, 129-148, 2002. 
Calmant, S., Seyler, F., and Cretaux, J.-F.: Monitoring Continental Surface Waters by Satellite Altimetry, Surv. Geophys., 29, $247-$ 269, 2008

Calver, A.: Riverbed Permeabilities: Information from Pooled Data, Ground Water, 39, 546-553, doi:10.1111/j.17456584.2001.tb02343.x, 2001.

Cardenas, M.: The effect of river bend morphology on flow and timescales of surface water - groundwater exchange across pointbars, J. Hydrol., 362, 134-141, doi:10.1016/j.jhydrol.2008.08.018, 2008a.

Cardenas, M.: Surface water-groundwater interface geomorphology leads to scaling f residence times, Geophys. Res. Lett., 35, doi:10.1029/2008GL033753, 2008b.

Cardenas, M.: Stream-aquifer interactions and hyporheic exchange in gaining and losing sinuous streams, Water Resour. Res., 45, W06469, doi:10.1029/2008WR007651, 2009a.

Cardenas, M.: A model for lateral hyporheic flow based on valley slope and channel sinuosity, Water Resour. Res., 45, W01501, doi:10.1029/2008WR007442, 2009b.

Cardenas, M. and Wilson, J.: Hydrodynamics of coupled flow above and below a sediment-water interface with triangular bedforms, Adv. Water Resour., 30, 301-313, doi:10.1016/j.advwatres.2006.06.009, 2007a.

Cardenas, M. and Wilson, J.: Dunes, turbulent eddies, and interfacial exchange with permeable sediments, Water Resour. Res., 43, W08412, doi:10.1029/2006WR005787, 2007b.

Cardenas, M. and Wilson, J.: Exchange across a sediment-water interface with ambient groundwater discharge, J. Hydrol., 346, 6980, doi:10.1016/j.jhydrol.2007.08.019, 2007c.

Cardenas, M., Wilson, J., and Zlotnik, V.: Impact of heterogeneity, bed forms, and stream curvature on subchannel hyporheic exchange, Water Resour. Res., 40, W08307, doi:10.1029/2004WR003008, 2004.

Carleton, J. and Montas, H.: An analysis of performance models for free water surface wetlands, Water Res., 44, 3595-3606, doi:10.1016/j.watres.2010.04.008, 2010.

Carroll, R., Pohll, G., and Hershey, R.: An unconfined groundwater model of the Death Valley Regional Flow System and a comparison to its confined predecessor, J. Hydrol., 373, 316-328, doi:10.1016/j.jhydrol.2009.05.006, 2009.

Chen, D. and MacQuarrie, K.: Numerical simulation of organic carbon, nitrate, and nitrogen isotope behavior during denitrification in a riparian zone, J. Hydrol., 293, 235-254, 2004.

Chen, X. and Chen, X.: Sensitivity analysis and determination of streambed leakance and aquifer hydraulic properties, J. Hydrol., 284, 270-284, 2003.

Chen, Y. and Durlofsky, L.: Adaptive local-global upscaling for general Flow scenarios in Heterogeneous formations, Trans. Porous Media, 62, 157-185, 2006.

Chung, I.-M., Kim, N.-W., Lee, J., and Sophocleous, M.: Assessing distributed groundwater recharge rate using integrated surface water-groundwater modelling: application to Mihocheon watershed, South Korea, Hydrogeol. J., 18, 1253-1264, doi:10.1007/s10040-010-0593-1, 2010.

Conan, C., Bouraoui, F., Turpin, N., de Marsily, G., and Bidoglio, G.: Modeling Flow and Nitrate Fate at Catchment Scale in Brittany (France), J. Environ. Qual., 32, 2026-2032, 2003.
Conant, B.: Delineating and Quantifying Ground Water Discharge Zones Using Streambed Temperatures, Ground Water, 42, 243 257, doi:10.1111/j.1745-6584.2004.tb02671.x, 2004.

Constantz, J.: Heat as a tracer to determine streambed water exchanges, Water Resour. Res., 44, 1-20, doi:10.1029/2008WR006996, 2008.

Constantz, J., Stewart, A., Niswonger, R., and Sarma, L.: Analysis of temperature profiles for investigating stream losses beneath ephemeral channels, Water Resour. Res., 38-12, 1316, doi:10.1029/2001WR001221, 2002.

Constantz, J., Eddy-Miller, C., Wheeler, J., and Essaid, H.: Streambed exchanges along tributary streams in humid watersheds, Water Resour. Res., 49, 2197-2204, doi:10.1002/wrcr.20194, 2013.

Cretaux, J.-F., Berge-Nguyen, M., Leblanc, M., Rio, R. A. D., Delclaux, F., Mognard, N., Lion, C., Pandey, R.-K., Tweed, S., Calmant, S., and Maisongrande, P.: Flood mapping inferred from remote sensing data, Int. Water Technol. J., 1, 48-62, 2011.

Crispell, J. and Endreny, T.: Hyporheic exchange flow around constructed in-channel structures and implications for restoration design, Hydrol. Process., 23, 1158-1168, doi:10.1002/hyp.7230, 2009.

Curie, F., Ducharne, A., Sebilo, M., and Bendjoudi, H.: Denitrification in a hyporheic riparian zone controlled by river regulation in the Seine river basin (France), Hydrol. Process., 23, 655-664, doi:10.1002/hyp.7161, 2009.

Dahl, M., Nilsson, B., Langhoff, J., and Refsgaard, J.: Review of classification systems and new multi-scale typology of groundwater-surface water interaction, J. Hydrol., 344, 1-16, 2007.

Dahm, C., Grimm, N., Marmonier, P., Valett, H., and Vervier, P.: Nutrient dynamics at the interface between surface waters and groundwaters, Freshwater Biol., 40, 427-451, doi:10.1046/j.1365-2427.1998.00367.x, 1998.

Dahm, C., Baker, M., Moore, D., and Thibault, J.: Coupled biogeochemical and hydrological responses of streams and rivers to drought, Freshwater Biol., 48, 1219-1231, doi:10.1046/j.13652427.2003.01082.x, 2003.

Dalrymple, R., W.: Incised valleys in time and space: an introduction to the volume and an examination of the controls on valley formation and filling, chap. Incised valleys in time and space, pp. Special Publication 85, SEPM, 5-12, doi:10.2110/pec.06.85.0005, 2006.

Datry, T., Dole-Olivier, M., Marmonier, P., Claret, C., Perrin, J., Lafont, M., and Breil, P.: La zone hyporhéique, une composante à ne pas négliger dans l'état des lieux et la restauration des cours d'eau, Ingénieries - E A T, 54, 3-18, 2008.

David, C., Habets, F., Maidment, D., and Yang, Z.-L.: RAPID applied to the SIM-France model, Hydrol. Process., 25, 3412-3425, doi:10.1002/hyp.8070, 2011.

Decharme, B., Douville, H., Prigent, C., Papa, F., and Aires, F.: A new river flooding scheme for global climate applications: Off-line evaluation over South America, J. Geophys. Res., 113, D11110, doi:10.1029/2007JD009376, 2008.

Decharme, B., Alkama, R., Douville, H., Becker, M., and Cazenave, A.: Global Evaluation of the ISBA-TRIP Continental Hydrological System. Part II: Uncertainties in River Routing Simulation Related to Flow Velocity and Groundwater Storage, J. Hydometeorol., 11, 601-617, doi:10.1175/2010JHM1212.1, 2010. 
Decharme, B., Alkama, R., Papa, F., Faroux, S., Douville, H., and Prigent, C.: Global off-line evaluation of the ISBA-TRIP flood model, Clim. Dynam., 38, 1389-1412, doi:10.1007/s00382-0111054-9, 2012.

Decharme, R. and Douville, H.: Global validation of the ISBA subgrid Hydrology, Clim. Dynam., 29, 21-37, doi:10.1007/s00382006-0216-7, 2007.

Deforet, T., Marmonier, P., Rieffel, D., Crini, N., Giraudoux, P., and Gilbert, D.: Do parafluvial zones have an impact in regulating river pollution? Spatial and temporal dynamics of nutrients, carbon, and bacteria in a large gravel bar of the Doubs River (France), Hydrobiologia, 623, 235-250, doi:10.1007/s10750008-9661-0, 2009.

Delfs, J.-O., Blumensaat, F., Wang, W., Krebs, P., and Kolditz, O.: Coupling hydrogeological with surface runoff model in a Poltva case study in Western Ukraine, Environ. Earth. Sci., 65, 14391457, doi:10.1007/s12665-011-1285-4, 2012.

de Marsily, G., Ledoux, E., Levassor, A., Poitrinal, D., and Salem, A.: Modelling of large multilayered aquifer systems: Theory and applications, J. Hydrol., 36, 1-34, 1978.

Derx, J., Blaschke, A., and Blöschl, G.: Three-dimensional flow patterns at the river-aquifer interface - a case study at the Danube, Adv. Water Resour., 33, 1375-1387, doi:10.1016/j.advwatres.2010.04.013, 2010.

Diem, S., Renard, P., and Schirmer, M.: Assessing the effect of different river water level interpolation schemes on modeled groundwater residence times, J. Hydrol., 510, 393-402, doi:10.1016/j.jhydrol.2013.12.049, 2014.

Discacciati, M., Miglio, E., and Quarteroni, A.: Mathematical and numerical models for coupling surface and groundwater flows, Appl. Numer. Math., 43, 57-74, 2002.

Dooge, J.: The hydrologic cycle as a closed system, Int. Assoc. Scient. Hydro. Bull., 13, 58-68, doi:10.1080/02626666809493568, 1968.

Doppler, T., Franssen, H.-J. H., Kaiser, H.-P., Kuhlman, U., and Stauffer, F.: Field evidence of a dynamic leakage coefficient for modelling river-aquifer interactions, J. Hydrol., 347, 177-187, doi:10.1016/j.jhydrol.2007.09.017, 2007.

Doussan, C., Poitevin, G., Ledoux, E., and Detay, M.: River bank filtration: modelling of the changes in water chemistry with emphasis on nitrogen species, J.f Contam. Hydrol., 25, 129-156, 1997.

Durand, M., Andreadis, K., Alsdorf, D., Lettenmaier, D., Moller, D., and Wilson, M.: Estimation of bathymetric depth and slope from data assimilation of swath altimetry into a hydrodynamic model, Geophys. Res. Lett., 35, L20401, doi:10.1029/2008GL034150, 2008.

Ebel, B. and Loague, K.: Physics-based hydrologic-response simulation: Seeing through the fog of equifinality, Hydrol. Process., 20, 2887-2900, 2006.

Ebel, B., Mirus, B. B., Heppner, C. S., VanderKwaak, J. E., and Loague, K.: First-order exchange coefficient coupling for simulating surface water-groundwater interactions: parameter sensitivity and consistency with a physics-based approach, Hydrol. Process., 23, 1949-1959, doi:10.1002/hyp.7279, 2009.
Ebrahim, G., Hamonts, K., van Griensven, A., Jonoski, A., Dejonghe, W., and Mynett, A.: Effect of temporal resolution of water level and temperature inputson numerical simulation of groundwater-surface water flux exchange in a heavily modified urban river, Hydrol. Process., 27, 1634-1645, doi:10.1002/hyp.9310, 2013.

Ellis, P., Mackay, R., and Rivett, M.: Quantifying urban riveraquifer fluid exchange processes: A multi-scale problem, J. Contam. Hydrol., 91, 58-80, 2007.

Endreny, T., Lautz, L., and Siegel, D.: Hyporheic flow path response to hydraulic jumps at river steps: Flume and hydrodynamic models, Water Resour. Res., 47, W02517, doi:10.1029/2009WR008631, 2011.

Engdahl, N., Volger, E., and Weissmann, G.: Evaluation of aquifer heterogeneity effects on river flow loss using a transition probability framework, Water Resour. Res., 46, W01506, doi:10.1029/2009WR007903, 2010.

Engeler, I., Hendricks Franssen, H., Müller, R., and Stauffer, F.: The importance of coupled modelling of variably saturated groundwater flow-heat transport for assessing river-aquifer interactions, J. Hydrol., 397, 295-305, doi:10.1016/j.jhydrol.2010.12.007, 2011.

Etchevers, P., Golaz, C., and Habets, F.: Simulation of the water budget and the river flows of the Rhone basin from 1981 to 1994 J. Hydrol., 244, 60-85, 2001.

Fan, Y., Li, H., and Miguez-Macho, G.: Global Patterns of Groundwater Table Depth, Science, 339, 940-943, doi:10.1126/science.1229881, 2013.

Fleckenstein, J., Niswonger., R., and Fogg, G.: River-Aquifer Interactions, Geologic Heterogeneity, and Low-Flow Management, Ground Water, 44, 837-852, doi:10.1111/j.17456584.2006.00190.x, 2006.

Fleckenstein, J., Krause, S., Hannah, D., and Boano, F.: Groundwater-surface water interactions: New methods and models to improve understanding of processes and dynamics, Adv. Water Resour., 33, 1291-1295, doi:10.1016/j.advwatres.2010.09.011, 2010.

Flipo, N.: Modélisation des Hydrosystèmes Continentaux pour une Gestion Durable de la Ressource en Eau, Ph.D. thesis, http://tel archives-ouvertes.fr/docs/00/87/94/49/PDF/flipo2013_hdr.pdf, Habilitation thesis, Université Pierre et Marie Curie, Paris VI, 2013.

Flipo, N., Even, S., Poulin, M., Théry, S., and Ledoux, E.: Modelling nitrate fluxes at the catchment scale using the integrated tool CAWAQS, Sci. Total Environ., 375, 69-79, doi:10.1016/j.scitotenv.2006.12.016, 2007a.

Flipo, N., Jeannée, N., Poulin, M., Even, S., and Ledoux, E.: Assessment of nitrate pollution in the Grand Morin aquifers (France): combined use of geostatistics and physically-based modeling, Environ. Pollut., 146, 241-256, doi:10.1016/j.envpol.2006.03.056, 2007b.

Flipo, N., Monteil, C., Poulin, M., de Fouquet, C., and Krimissa, M.: Hybrid fitting of a hydrosystem model: long term insight into the Beauce aquifer functioning (France), Water Resour. Res., 48, W05509, doi:10.1029/2011WR011092, 2012.

Freeze, R.: Three-Dimensional, Transient, Saturated-Unsaturated Flow in a Groundwater Basin, Water Resour. Res., 7, 347-366, 1971. 
Frei, S., Fleckenstein, J., Kollet, S., and Maxwell, R.: Patterns and dynamics of river-aquifer exchange with variably-saturated flow using a fully-coupled model, J. Hydrol., 375, 383-393, doi:10.1016/j.jhydrol.2009.06.038, 2009.

Frei, S., Lischeid, G., and Fleckenstein, J.: Effects of microtopography on surface-subsurface exchange and runoff generation in a virtual riparian wetland - A modeling study, Adv. Water Resour., 33, 1388-1401, doi:10.1016/j.advwatres.2010.07.006, 2010.

Frei, S., Knorr, K., Peiffer, S., and Fleckenstein, J.: Surface microtopography causes hot spots of biogeochemical activity in wetland systems: A virtual modeling experiment, J. Geophys. Res., 117, G00N12, doi:10.1029/2012JG002012, 2012.

Furman, A.: Modeling Coupled Surface-Subsurface Flow Processes: A Review, Vadose Zone J., 7, 741-756, doi:10.2136/vzj2007.0065, 2008.

Galbiati, L., Bouraoui, F., Elorza, F., and Bidoglio, G.: Modeling diffuse pollution loading into a Mediterranean lagoon: Development and application of an integrated surface-subsurface model tool, Ecol. Model., 193, 4-18, doi:10.1016/j.ecolmodel.2005.07.036, 2006.

Gao, H., Birkett, C., and Lettenmaier, D.: Global monitoring of large reservoir storage from satellite remote sensing, Water Resour. Res., 48, W09504, doi:10.1029/2012WR012063, 2012.

García-García, D., Ummenhofer, C., and Zlotnicki, V.: Australian water mass variations from GRACE data linked to Indo-Pacific climate variability, Remote Sens. Environ., 115, 2175-2183, doi:10.1016/j.rse.2011.04.007, 2011.

Gariglio, F. P., Tonina, D., and Luce, C. H.: Spatiotemporal variability of hyporheic exchange through a pool-riffle-pool sequence, Water Resour. Res., 49, 7185-7204, doi:10.1002/wrcr.20419, 2013.

Genereux, D. P., Leahy, S., Mitasova, H., Kennedy, C. D., and Corbett, D. R.: Spatial and temporal variability of streambed hydraulic conductivity in West Bear Creek, North Carolina, USA, J. Hydrol., 358, 332-353, doi:10.1016/j.jhydrol.2008.06.017, 2008.

Getirana, A., Boone, A., Yamazaki, D., and Mognard, N.: Automatic parametrization of a flow routing scheme driven by radar altimetry data: evaluation in the Amazon basin, Water Resour. Res., 49, 614-629, doi:10.1002/wrcr.20077, 2013.

Gibling, M., R., Fielding, C., R., and Sinha, R.: Alluvial valleys and alluvial sequences: towards a geomorphic assessment, in: chap. From river to rock record: The preservation of fluvial sediments and their subsequent interpretation, SEPM Special Publication No. 97, SEPM, 423-447, 2011.

Gleeson, T. and Paszkowski, D.: Perceptions of scale in hydrology: what do you mean by regional scale?, Hydrolog. Sci. J., 59, 1-9, doi:10.1080/02626667.2013.797581, 2013.

Goderniaux, P., Brouyère, S., Fowler, H., Blenkinsop, S., Therrien, R., Orban, P., and Dassargues, A.: Large scale surface-subsurface hydrological model to assess climate change impacts on groundwater reserves, J. Hydrol., 373, 122-138, 2009.

Golaz-Cavazzi, C., Etchevers, P., Habets, F., Ledoux, E., and Noilhan, J.: Comparison of two hydrological simulations of the Rhône basin, Phys. Chem. Earth, 26, 461-466, 2001.
Gomez, E., Ledoux, E., Viennot, P., Mignolet, C., Beno^t, M., Bornerand, C., Schott, C., Mary, B., Billen, G., Ducharne, A., and Brunstein, D.: Un outil de modélisation intégrée du transfert des nitrates sur un système hydrologique: Application au bassin de la Seine, La Houille Blanche, 3-2003, 38-45, 2003.

Gomez, J., Wilson, J., and Cardenas, M.: Residence time distributions in sinuosity-driven hyporheic zones and their biogeochemical effects, Water Resour. Res., 48, W09533, doi:10.1029/2012WR012180, 2012.

Gooseff, M., Anderson, J., Wondzell, S., LaNier, J., and Haggerty, R.: A modelling study of hyporheic exchange pattern and the sequence, size, and spacing of stream bedforms in mountain stream networks, Oregon, USA, Hydrol. Process., 20, 2443 2457, doi:10.1002/hyp.6349, 2006.

Graillot, D., Paran, F., Bornette, G., Marmonier, P., Piscart, C., and Cadilhac, L.: Coupling groundwater modeling and biological indicators for identifying river/aquifer exchanges, SpringerPlus, 3 , 68, doi:10.1186/2193-1801-3-68, 2014.

Gu, C., Hornberger, G., Herman, J., and Mills, A.: Influence of stream-groundwater interactions in the streambed sediments on $\mathrm{NO}_{3}^{-}$flux to a low-relief coastal stream, Water Resour. Res., 44, W11432, doi:10.1029/2007WR006739, 2008.

Gu, C., Anderson, W., and Maggi, F.: Riparian biogeochemical hot moments induced by stream fluctuations, Water Resour. Res., 48, W09546, doi:10.1029/2011WR011720, 2012.

Gunduz, O. and Aral, M.: River networks and groundwater flow: a simultaneous solution of a coupled system, J. Hydrol., 301, 216234, doi:10.1016/j.jhydrol.2004.06.034, 2005.

Habets, F., Noilhan, J., Golaz, C., Goutorbe, J., Lacarrère, P., Leblois, E., Ledoux, E., Martin, E., Ottlé, C., and Vidal-Madjar, D.: The ISBA surface scheme in a macroscale hydrological model applied to the Hapex-Mobilhy area Part I: Model and database, J. Hydrol., 217, 75-96, 1999.

Haitjema, H.: Comparing a three-dimensionnal and a DupuitForchheimer solution for a circula recharge area in a confined aquifer, J. Hydrol., 91, 83-101, 1987.

Haitjema, H.: On the residence time distribution in idealized groundwatersheds, J. Hydrol., 172, 127-146, 1995.

Hancock, P., Boulton, A., and Humphreys, W.: Aquifers and hyporheic zones: Towards an ecological understanding of groundwater, Hydrogeol. J., 13, 98-111, doi:10.1007/s10040-004-04216, 2005.

Hanson, R., Schmid, W., Faunt, C., and Lockwood, B.: Simulation and Analysis of Conjunctive Use with MODFLOW's Farm Process, Ground Water, 48, 674-689, doi:10.1111/j.17456584.2010.00730.x, 2010.

Harbaugh, A., Banta, E., Hill, M., and McDonald, M.: MODFLOW2000, the U.S. Geological Survey modular ground-water model: User guide to modularization concepts and the ground-water flow process, Tech. Rep. 00-92, USGS, Denver, Colorado, USA, 2000.

Harvey, A.: Effective timescales of coupling within fluvial systems, Geomorphology, 44, 175-201, 2002.

Harvey, J. and Bencala, K.: The effect of streambed topography on surface-subsurface water exchange in mountain catchments, Water Resour. Res., 29, 89-98, 1993. 
Hatch, C., Fisher, A., Revenaugh, J., Constantz, J., and Ruehl, C.: Quantifying surface water-groundwater interactions using time series analysis of streambed thermal records: Method development, Water Resour. Res., 42, W10410, doi:10.1029/2005WR004787, 2006.

Hatch, C., Fisher, A., Ruehl, C., and Stemler, G.: Spatial and temporal variations in streambed hydraulic conductivity quantified with time-series thermal methods, J. Hydrol., 389, 276-288, 2010.

Hayashi, M. and Rosenberry, D.: Effects of Ground Water Exchange on the Hydrology and Ecology of Surface Water, Ground Water, 40, 309-316, 2002.

Heeren, D. M., Fox, G. A., Fox, A. K., Storm, D. E., Miller, R. B., and Mittelstet, A. R.: Divergence and flow direction as indicators of subsurface heterogeneity and stage-dependent storage in alluvial floodplains, Hydrol. Process., 28, 1307-1317, doi:10.1002/hyp.9674, 2014.

Hefting, M., Clément, J., Dowrick, D., Cosandey, A., Bernal, S., Cimpian, C., Tatur, A., Burt, T., and Pinay, G.: Water table elevation controls on soil nitrogen cycling in riparian wetlands along a European climatic gradient, Biogeochemistry, 67, 113134, 2004

Heinz, J., Kleineidam, S., Teutsch, G., and Aigner, T.: Heterogeneity patterns of Quaternary glaciofluvial gravel bodies (SWGermany): application to hydrogeology, Sediment. Geol., 158, 1-23, doi:10.1016/S0037-0738(02)00239-7, 2003.

Henriksen, H., Troldborg, L., Hojberg, A., and Refsgaard, J.: Assessment of exploitable groundwater resources of Denmark by use of ensemble resource indicators and a numerical groundwater-surface water model, J. Hydrol., 348, 224-240, 2008.

Hester, E. and Doyle, M.: In-stream geomorphic structures as drivers of hyporheic exchange, Water Resour. Res., 44, W03417, doi:10.1029/2006WR005810, 2008.

Hill, M., Cooley, R., and Pollock, D.: A Controlled Experiment in Ground Water Flow Model Calibration, Ground Water, 36, 520 $535,1998$.

Hornung, J. and Aigner, T.: Reservoir and aquifer characterization of fluvial architectural elements: Stubensandstein, Upper Triassic, southwest Germany, Sediment. Geol., 129, 215-280, doi:10.1016/S0037-0738(99)00103-7, 1999.

Irvine, D., Brunner, P., Hendricks Franssen, H.-J., and Simmons, G.: Heterogeneous or homogeneous? Implications of simplifying heterogeneous streambeds in models of losing streams, J. Hydrol., 424-425, 16-23, doi:10.1016/j.jhydrol.2011.11.051, 2012.

Janssen, F., Cardenas, M., Sawyer, A., Dammrich, T., Krietsch, J., and de Beer, D.: A comparative experimental and multiphysics computational fluid dynamics study of coupled surfacesubsurface flow in bed forms, Water Resour. Res., 48, W08514, doi:10.1029/2012WR011982, 2012.

Jencso, K., McGlynn, B., Gooseff, M., Bencala, K., and Wondzell, S.: Hillslope hydrologic connectivity controls riparian groundwater turnover: Implications of catchment structure for riparian buffering and stream water sources, Water Resour. Res., 46, W10524, doi:10.1029/2009WR008818, 2010.

Jensen, J. and Engesgaard, P.: Nonuniform Groundwater Discharge across a Streambed: Heat as a Tracer, Vadose Zone J., 10, 98 109, doi:10.2136/vzj2010.0005, 2011.
Jolly, I. and Rassam, D.: A review of modelling of groundwatersurface water interactions in arid/semi-arid floodplains, in: 18th World IMACS/MODSIM Congress, Cairns, Australia, 2009.

Kalbus, E., Schmidt, C., Molson, J. W., Reinstorf, F., and Schirmer, M.: Influence of aquifer and streambed heterogeneity on the distribution of groundwater discharge, Hydrol. Earth Syst. Sci., 13, 69-77, doi:10.5194/hess-13-69-2009, 2009.

Kasahara, T. and Hill, A.: Hyporheic exchange flows induced by constructed riffles and steps in lowland streams in southern Ontario, Canada, Hydrol. Process., 20, 4287-4305, doi:10.1002/hyp.6174, 2006.

Kasahara, T. and Wondzell, S.: Geomorphic controls on hyporheic exchange flow in mountain streams, Water Resour. Res., 39, 1005, doi:10.1029/2002WR001386, 2003.

Käser, D., Binley, A., Heathwaite, A., and Krause, S.: Spatiotemporal variations of hyporheic flow in a riffle-step-pool sequence, Hydrol. Process., 23, 2138-2149, doi:10.1002/hyp.7317, 2009.

Käser, D., Binley, A., and Heathwaite, A.: On the importance of considering channel microforms in groundwater models of hyporheic exchange, River Res. Appl., 29, 528-535, doi:10.1002/rra.1618, 2013.

Käser, D., Graf, T., Cochand, F., McLaren, R., Therrien, R., and Brunner, P.: Channel Representation in Physically Based Models Coupling Groundwater and Surface Water: Pitfalls and How to Avoid Them, Ground Water, doi:10.1111/gwat.12143, in press, 2014.

Ke, K.-Y.: Application of an integrated surface water-groundwater model to multi-aquifers modeling in Choushui River alluvial fan, Taiwan, Hydrol. Process., 28, 1409-1421, doi:10.1002/hyp.9678, 2014.

Keery, J., Binley, A., Crook, N., and Smith, J.: Temporal and spatial variability of groundwater-surface water fluxes: Development and application of an analytical method using temperature time series, J. Hydrol., 336, 1-16, doi:10.1016/j.jhydrol.2006.12.003, 2007.

Kikuchi, C., Ferré, T., and Welker, J.: Spatially telescoping measurements for improved characterization of ground water-surface water interactions, J. Hydrol., 446-447, 1-12, doi:10.1016/j.jhydrol.2012.04.002, 2012.

Kim, N., Chung, I., Won, Y., and Arnold, J.: Development and application of the integrated SWAT-MODFLOW model, J. Hydrol., 356, 1-16, doi:10.1016/j.jhydrol.2008.02.024, 2008.

Kjellin, J., Hallin, S., and Wörman, A.: Spatial variations in denitrification activity in wetland sediments explained by hydrology and denitrifying community structure, Water Res., 41, 4710 4720, doi:10.1016/j.watres.2007.06.053, 2007.

Klemes, V.: Conceptualization and scale in hydrology, J. Hydrol., 65, 1-23, 1983.

Klingbeil, R., Kleineidam, S., Asprion, U., Aigner, T., and Teutsch, G.: Relating lithofacies to hydrofacies: outcrop-based hydrgeological characterisation of Quaternary gravel deposits, Sediment. Geol., 129, 299-310, doi:10.1016/S0037-0738(99)000676, 1999. 
Koch, J., McKnight, D., and Neupauer, R.: Simulating unsteady flow, anabranching, and hyporheic dynamics in a glacial meltwater stream using a coupled surface water routing and groundwater flow model, Water Resour. Res., 47, W05530, doi:10.1029/2010WR009508, 2011.

Kolditz, O., Delfs, J., Bürger, C., Beinhorn, M., and Parkee, C.: Numerical analysis of coupled hydrosystems based on an objectoriented compartment approach, J. Hydroinform., 10, 227-244, 2008.

Kolditz, O., Bauer, S., Beyer, C., Böttcher, N., Dietrich, P., Görke, U.-J., Kalbacher, T., Park, C.-H., Sauer, U., Schütze, C., Shao, H., Singh, A., Taron, J., Wang, W., and Watanabe, N.: A systematic benchmarking approach for geologic $\mathrm{CO}_{2}$ injection and storage, Environ. Earth. Sci., 67, 613-632, doi:10.1007/s12665012-1656-5, 2012.

Kollet, S. J. and Maxwell, R. M.: Integrated surface-groundwater flow modeling: A free-surface overland flow boundary condition in a parallel groundwater flow model, Adv. Water Resour., 29, 945-958, 2006.

Kollet, S. J., Maxwell, R. M., Woodward, C., Smith, S., Vanderborght, J., Vereecken, H., and Simmer, C.: Proof of concept of regional scale hydrologic simulations at hydrologic resolution utilizing massively parallel computer, Water Resour. Res., 46, W04201, doi:10.1029/2009WR008730, 2010.

Koltermann, C. E. and Gorelick, S. M.: Heterogeneity in sedimentary deposits: A review of structure-imitating, process-imitating, and descriptive approaches, Water Resour. Res., 32, 2617-2658, doi:10.1029/96WR00025, 1996.

Koussis, A., Akylas, E., and Mazi, K.: Response of sloping unconfined aquifer to stage changes in adjacent stream II. Applications, J. Hydrol., 338, 73-84, doi:10.1016/j.jhydrol.2007.02.030, 2007.

Krause, S. and Bronstert, A.: The impact of groundwater-surface water interactions on the water balance of a mesoscale lowland river catchment in northeastern Germany, Hydrol. Process., 21, 169-184, doi:10.1002/hyp.6182, 2007.

Krause, S., Bronstert, A., and Zehe, E.: Groundwater-surface water interactions in a North German lowland floodplain - Implications for the river discharge dynamics and riparian water balance, J. Hydrol., 347, 404-417, doi:10.1016/j.jhydrol.2007.09.028, 2007.

Krause, S., Hannah, D., and Fleckenstein, J.: Hyporheic hydrology: interactions at the groundwater-surface water interface, Hydrol. Process., 23, 2103-2107, doi:10.1002/hyp.7366, 2009a.

Krause, S., Heathwaite, L., Binley, A., and Keenan, P.: Nitrate concentration changes at the groundwater-surface water interface of a small Cumbrian River, Hydrol. Process., 23, 2195-2211, doi:10.1002/hyp.7213, 2009b.

Krause, S., Hannah, D. M., Fleckenstein, J. H., Heppell, C. M., Kaeser, D., Pickup, R., Pinay, G., Robertson, A. L., and Wood, P. J.: Inter-disciplinary perspectives on processes in the hyporheic zone, Ecohydrology, 4, 481-499, doi:10.1002/eco.176, 2011.

Krause, S., Blume, T., and Cassidy, N. J.: Investigating patterns and controls of groundwater up-welling in a lowland river by combining Fibre-optic Distributed Temperature Sensing with observations of vertical hydraulic gradients, Hydrol. Earth Syst. Sci., 16, 1775-1792, doi:10.5194/hess-16-1775-2012, 2012a.
Krause, S., Munz, M., Tecklenburg, C., and Binley, A.: The effect of groundwater forcing on hyporheic exchange: Reply to comment on "Munz M., Krause S., Tecklenburg C., Binley A., Reducing monitoring gaps at the aquifer-river interface by modelling groundwater-surfacewater exchange flow patterns, Hydrological Processes, doi:10.1002/hyp.8080", Hydrol. Process., 26, 15891592, doi:10.1002/hyp.9271, 2012b.

Kurtulus, B., Flipo, N., Goblet, P., Vilain, G., Tournebize, J., and Tallec, G.: Hydraulic head interpolation in an aquifer unit using ANFIS and Ordinary Kriging, in: Studies in computational intelligence, Springer, 343, 265-273, doi:10.1007/978-3-642-202063_18, 2011.

LaBolle, E., Ahmed, A., and Fogg, G.: Review of the Integrated Groundwater and Surface-Water Model (IGSM), Ground Water, 41, 238-246, 2003.

Lautz, L. and Siegel, D.: Modeling surface and ground water mixing in the using MODFLOW and MT3D, Adv. Water Resour., 29, 1618-1633, doi:10.1016/j.advwatres.2005.12.003, 2006.

Lautz, L., Kranes, N., and Siegel, D.: Heat tracing of heterogeneous hyporheic exchange adjacent to in-stream geomorphic features, Hydrol. Process., 24, 3074-3086, doi:10.1002/hyp.7723, 2010.

Ledoux, E., Girard, G., de Marsily, G., Villeneuve, J., and Deschenes, J.: Unsaturated flow in hydrologic modeling - theory and practice, in: chap. Spatially distributed modeling: conceptual approach, coupling surface water and groundwater, NATO ASI Ser. CNorwell, Springer, Kluwer Academicy, Massachussetts, 435-454, 1989.

Ledoux, E., Gomez, E., Monget, J., Viavattene, C., Viennot, P., Ducharne, A., Benoit, M., Mignolet, C., Schott, C., and Mary, B.: Agriculture and groundwater nitrate contamination in the Seine basin. The STICS-MODCOU modelling chain, Sci. Total Environ., 375, 33-47, 2007.

Leek, R., Wu, J., Wang, L., Hanrahan, T., Barber, M., and Qiu, H.: Heterogeneous characteristics of streambed saturated hydraulic conductivity of the Touchet River, south eastern Washington, USA, Hydrol. Process., 23, 1236-1246, doi:10.1002/hyp.7258, 2009.

Lemieux, J. and Sudicky, E.: Simulation of groundwater age evolution during the Wisconsinian glaciation over the Canadian landscape, Environ. Fluid Mech., 10, 91-102, 2010.

Lewandowski, J., Angermann, L., Nützmann, G., and Fleckenstein, J.: A heat pulse technique for the determination of small-scale flow directions and flow velocities in the streambed of sand-bed streams, Hydrol. Process., 25, 3244 3255, doi:10.1002/hyp.8062, 2011.

Li, Q., Unger, A., Sudicky, E., Kassenaar, D., Wexler, E., and Shikaze, S.: Simulating the multi-seasonal response of a largescale watershed with a $3 \mathrm{D}$ physically-based hydrologic model, J. Hydrol., 357, 317-336, 2008.

Liang, D., Falconer, R., and Lin, B.: Coupling surface and subsurface flows in a depth averaged flood wave model, J. Hydrol., 337, 147-158, doi:10.1016/j.jhydrol.2007.01.045, 2007.

Liggett, J., Werner, A., and Simmons, C.: Influence of the first-order exchange coefficient on simulation of coupled surface-subsurface flow, J. Hydrol., 414-415, 503-515, doi:10.1016/j.jhydrol.2011.11.028, 2012.

Loague, K. and VanderKwaak, J.: Physics-based hydrologic response: platinium bridge, 1958 Edsel, or useful tool, Hydrol. Process., 18, 2949-2956, 2004. 
Luce, C., Tonina, D., Gariglio, F., and Applebee, R.: Solutions for the diurnally forced advection-diffusion equation to estimate bulk fluid velocity and diffusivity in streambeds from temperature time series, Water Resour. Res., 49, 1-19, doi:10.1029/2012WR012380, 2013.

Macpherson, G. and Sophocleous, M.: Fast ground-water mixing and basal recharge in an unconfined, alluvial aquifer, Konza LTER Site, Northeastern Kansas, J. Hydrol., 286, 271-299, 2004.

Maier, H. and Howard, K.: Influence of Oscillating Flow on Hyporheic Zone Development, Ground Water, 49, 830-844, doi:10.1111/j.1745-6584.2010.00794.x, 2011.

Malard, F., Tockner, K., Dole-Olivier, M.-J., and Ward, J. V.: A landscape perspective of surface-subsurface hydrological exchanges in river corridors, Freshwater Biol., 47, 621-640, 2002.

Marion, A., Packman, A., Zaramella, M., and Bottacin-Busolin, A.: Hyporheic flows in stratified beds, Water Resour. Res., 44, W09433, doi:10.1029/2007WR006079, 2008.

Marmonier, P., Archambaud, G., Belaidi, N., Bougon, N., Breil, P., Chauvet, E., Claret, C., Cornut, J., Datry, T., Dole-Olivier, M., Dumont, B., Flipo, N., Foulquier, A., Gérino, M., Guilpart, A., Julien, F., Maazouzi, C., Martin, D., Mermillod-Blondin, F., Montuelle, B., Namour, P., Navel, S., Ombredane, D., Pelte, T., Piscart, C., Pusch, M., Stroffek, S., Robertson, A., SanchezPérez, J., Sauvage, S., Taleb, A., Wantzen, M., and Vervier, P.: The role of organisms in hyporheic processes: gaps in current knowledge, needs for future research and applications, Ann. Limnol. - Int. J. Limnol., 48, 253-266, 2012.

Marzadri, A., Tonina, D., Bellin, A., Vignoli, G., and Tubino, M.: Semianalytical analysis of hyporheic flow induced by alternate bars, Water Resour. Res., 46, W07531, doi:10.1029/2009WR008285, 2010.

Marzadri, A., Tonina, D., and Bellin, A.: A semianalytical threedimensional process-based model for hyporheic nitrogen dynamics in gravel bed rivers, Water Resour. Res., 47, W11518, doi:10.1029/2011WR010583, 2011.

Massei, N., Laignel, B., Deloffre, J., Mesquita, J., Motelay, A., Lafite, R., and Durand, A.: Long-term hydrological changes of the Seine River flow (France) and their relation to the North Atlantic Oscillation over the period 1950-2008, Int. J. Climatol., 30, 2146-2154, doi:10.1002/joc.2022, 2010.

Masson, V., Le Moigne, P., Martin, E., Faroux, S., Alias, A., Alkama, R., Belamari, S., Barbu, A., Boone, A., Bouyssel, F., Brousseau, P., Brun, E., Calvet, J.-C., Carrer, D., Decharme, B., Delire, C., Donier, S., Essaouini, K., Gibelin, A.-L., Giordani, H., Habets, F., Jidane, M., Kerdraon, G., Kourzeneva, E., Lafaysse, M., Lafont, S., Lebeaupin Brossier, C., Lemonsu, A., Mahfouf, J.-F., Marguinaud, P., Mokhtari, M., Morin, S., Pigeon, G., Salgado, R., Seity, Y., Taillefer, F., Tanguy, G., Tulet, P., Vincendon, B., Vionnet, V., and Voldoire, A.: The SURFEXv7.2 land and ocean surface platform for coupled or offline simulation of earth surface variables and fluxes, Geosci. Model Dev., 6, 929-960, doi:10.5194/gmd-6-929-2013, 2013.

Maxwell, R. and Miller, N.: Development of a Coupled Land Surface and Groundwater Model, J. Hydrometeorol., 6, 233-247, 2005 .
McDonald, M. and Harbaugh, A.: MODFLOW, a modular threedimensional finite-difference ground-water flow model, in: Book 6, chap A1, p Technique of Water Ressources Investigations of the US Geological Survey, USGS Federal Center, Denver, Colorado, p. 586, 1988.

McGuire, K. and McDonnell, J.: A review and evaluation of catchment transit time modeling, J. Hydrol., 330, 543-563, doi:10.1016/j.jhydrol.2006.04.020, 2006.

Mehl, S. and Hill, M.: Developement and evaluation of a local grid refinement method forblock-centred finite-difference groundwater models using shared nodes, Adv. Water Resour., 25, 497-511, 2002.

Mehl, S. and Hill, M.: Grid-size dependence of Cauchy boundary conditon used to simulate stream-aquifer interactions, Adv. Water Resour., 33, 430-442, 2010.

Miall, A., D.: The geology of fluvial deposits, Springer Verlag, Berlin, Heidelberg, 1996.

Michailovsky, C., Milzow, C., and Bauer-Gottwein, P.: Assimilation of radar altimetry to a routing model of the Brahmaputra river, Water Resour. Res., 49, 4807-4816, doi:10.1002/wrcr.20345, 2013.

Miglio, E., Quarteroni, A., and Saleri, F.: Coupling of free surface and groundwater flows, Comput. Fluids, 32, 73-83, 2003.

Monteil, C.: Estimation de la contribution des principaux aquifères du bassin-versant de la Loire au fonctionnement hydrologique du fleuve à l'étiage, Ph.D. thesis, MINES-ParisTech, Paris, 2011.

Morel-Seytoux, J.: The turning factor in the Estimation of stream aquifer seepage, Ground Water, 42, 205-212, 2009.

Mouhri, A., Flipo, N., Rejiba, F., de Fouquet, C., Bodet, L., Goblet, P., Kurtulus, B., Ansart, P., Tallec, G., Durand, V., and Jost, A.: Designing a multi-scale sampling system of stream-aquifer interfaces in a sedimentary basin, J. Hydrol., 504, 194-206, doi:10.1016/j.jhydrol.2013.09.036, 2013.

Munz, M., Krause, S., Tecklenburg, C., and Binley, A.: Reducing monitoring gaps at the aquifer-river interface by modelling groundwater-surface water exchange flow patterns, Hydrol. Process., 25, 3547-3562, doi:10.1002/hyp.8080, 2011.

Mutiti, S. and Levy, J.: Using temperature modeling to investigate the temporal variability of riverbed hydraulic conductivity during storm events, J. Hydrol., 388, 321-334, 2010.

Nalbantis, I., Efstratiadis, A., Rozos, E., Kopsiafti, M., and Koutsoyiannis, D.: Holistic versus monomeric strategies for hydrological modelling of human-modified hydrosystems, Hydrol. Earth Syst. Sci., 15, 743-758, doi:10.5194/hess-15-743-2011, 2011.

Nanson, G. C. and Croke, J.: A genetic classification of floodplains, Geomorphology, 4, 459-486, doi:10.1016/0169555X(92)90039-Q, 1992.

Neal, J., Schumann, G., Bates, P., Buytaert, W., Matgen, P., and Pappenberger, F.: A data assimilation approach to discharge estimation from space, Hydrol. Process., 23, 3641-3649, doi:10.1002/hyp.7518, 2009.

Nemeth, M. and Solo-Gabriele, H.: Evaluation of the use of reach transmissivity to quantify exchange between groundwater and surface water, J. Hydrol., 274, 145-159, doi:10.1016/S00221694(02)00419-5, 2003.

Noto, L., Ivanov, V., Bras, R., and Vivoni, E.: Effects of initialization on response of a fully-distributed hydrologic model, J. Hydrol., 352, 107-125, doi:10.1016/j.jhydrol.2007.12.031, 2008. 
O’Driscoll, M., Johnson, P., and Mallinson, D.: Geological controls and effects of floodplain asymmetry on river-groundwater interactions in the southeastern Coastal Plain, USA, Hydrogeol. J., 18, 1265-1279, doi:10.1007/s10040-010-0595-z, 2010.

Oeurng, C., Sauvage, S., and Sánchez-Pérez, J.-M.: Temporal variability of nitrate transport through hydrological response during flood events within a large agricultural catchment in south-west France, Sci. Total Environ., 409, 140-149, doi:10.1016/j.scitotenv.2010.09.006, 2010.

Oki, T. and Sud, Y.: Design of total runoff integrating pathways (TRIP). A global river channel network, Earth Interact., 2, 1-36, 1998.

O’Loughlin, F., Trigg, M., Schumann, G., and Bates, P.: Hydraulic characterization of the middle reach of the Congo River, Water Resour. Res., 49, 5059-5070, 2013.

Osman, Y. and Bruen, M.: Modelling stream-aquifer seepage in an alluvial aquifer: an improved loosing-stream package for MODFLO, J. Hydrol., 264, 69-86, 2002.

Pan, M., Wood, E., Wójcik, R., and McCabe, M.: Estimation of regional terrestrial water cycle using multi-sensor remote sensing observations and data assimilation, Remote Sens. Environ., 112, 1282-1294, doi:10.1016/j.rse.2007.02.039, 2008.

Panday, S. and Huyakorn, P. S.: A fully coupled physicallybased spatially-distributed model for evaluating surface/subsurface flow, Adv. Water Resour., 27, 361-382, doi:10.1016/j.advwatres.2004.02.016, 2004.

Paola, C. and Borgman, L.: Reconstructing random topography from preserved stratification, Sedimentology, 38, 553-565, 1991.

Park, Y.-J., Sudicky, E., Panday, S., and Matanga, G.: Implicit Subtime Stepping for Solving Nonlinear Flow Equations in an integrated Surface-Subsurface System, Vadose Zone J., 8, 825-836, doi:10.2136/vzj2009.0013, 2009.

Parkin, G., O’Donnell, G., Ewen, J., Bathurst, J., O'Connell, P., and Lavabre, J.: Validation of catchment models for predicting landuse and climate change impacts. 2. Case study for a Mediterranean catchment, J. Hydrol., 175, 595-613, 1996.

Parliament Council of the European Union: Dir. 2000/60/EC, establishing a framework for community action in the field of water policy, http:///ec.europa.eu/environment/water/ water-framework/ (last access: 10 August 2014), 2000.

Perkins, S. and Sophocleous, M.: Development of a Comprehensive Watershed Model Applied to Study Stream Yield under Drought Conditions, Ground Water, 37, 418-426, 1999.

Peterson, E. and Sickbert, T.: Stream water bypass through a meander neck, laterally extending the hyporheic zone, Hydrogeol. J., 14, 1443-1451, 2006.

Peyrard, D., Sauvage, S., Vervier, P., Sanchez-Perez, J., and Quintard, M.: A coupled vertically integrated model to describe lateral exchanges between surface and subsurface in large alluvial floodplains with a fully penetrating river, Hydrol. Process., 22, 4257-4273, doi:10.1002/hyp.7035, 2008.

Peyrard, D., Delmotte, S., Sauvage, S., Namour, P., Gerino, M., Vervier, P., and Sanchez-Perez, J.: Longitudinal transformation of nitrogen and carbon in the hyporheic zone of an N-rich stream: A combined modelling and field study, Phys. Chem. Earth, 36, 599-611, doi:10.1016/j.pce.2011.05.003, 2011.

Pinder, G. and Jones, J.: Determination of the groundwater component of peak discharge from the chemistry of total run-off, Water Resour. Res., 5, 438-445, 1969.
Polus, E., Flipo, N., de Fouquet, C., and Poulin, M.: Geostatistics for assessing the efficiency of distributed physically-based water quality model. Application to nitrates in the Seine River, Hydrol. Process., 25, 217-233, doi:10.1002/hyp.7838, 2011.

Poole, G. C., O’Daniel, S. J., Jones, K. L., Woessner, W. W., Bernhardt, E. S., Helton, A. M., Stanford, J. A., Boer, B. R., and Beechie, T. J.: Hydrologic spiralling: The role of multiple interactive flow paths in stream ecosystems, River Res. Appl., 24, 1018-1031, doi:10.1002/rra.1099, 2008.

Poole, G. C., Stanford, J. A., Frissell, C. A., and Running, S. W.: Three-dimensional mapping of geomorphic controls on floodplain hydrology and connectivity from aerial photos, Geomorphology, 48, 329-347, doi:10.1016/S0169-555X(02)000788, 2002.

Pryet, A., Labarthe, B., Saleh, F., Akopian, M., and Flipo, N.: Quantification of stream-aquifer flow distribution at the regional scale with a distributed process-based model, Water Resour. Manage., accepted, 2014.

Qu, Y. and Duffy, C.: A semidiscrete finite volume formulation for multiprocess watershed simulation, Water Resour. Res., 43, W08419, doi:10.1029/2006WR005752, 2007.

Ramillien, G., Famiglietti, J., and Wahr, J.: Detection of continental hydrology and glaciology signals from GRACE: A review, Surv. Geophys., 29, 361-374, doi:10.1007/s10712-008-9048-9, 2008.

Ramillien, G., Seoane, L., Frappart, F., Biancale, R., Gratton, S., Vasseur, X., and Bourgogne, S.: Constrained Regional Recovery of Continental Water Mass Time-variations from GRACE-based Geopotential Anomalies over South America, Surv. Geophys., 33, 887-905, doi:10.1007/s10712-012-9177-z, 2012.

Ramireddygari, S., Sophocleous, M., Koelliker, J., Perkins, S., and Govindaraju, R.: Development and application of a comprehensive simulation model to evaluate impacts of watershed structures and irrigation water use on streamflow and groundwater: the case of Wet Walnut Creek Watershed, Kansas, USA, J. Hydrol., 236, 223-246, 2000.

Rau, G., Andersen, M., McCallum, A., and Acworth, R.: Analytical methods that use natural heat as a tracer to quantify surface water-groundwater exchange, evaluated using field temperature records, Hydrogeol. J., 18, 1093-1110, 2010.

Refsgaard, J. and Knudsen, J.: Operational validation and intercomparison of different types of hydrological models, Water Resour. Res., 32, 2189-2202, 1996.

Refsgaard, J. C., Christensen, S., Sonnenborg, T. O., Seifert, D., Højberg, A. L., and Troldborg, L.: Review of strategies for handling geological uncertainty in groundwater flow and transport modeling, Adv. Water Resour., 36, 36-50, doi:10.1016/j.advwatres.2011.04.006, 2012.

Renard, P.: Calculating equivalent permeability: A review, Adv. Water Resour., 20, 253-278, 1997.

Revelli, R., Boano, F., Camporeale, C., and Ridolfi, L.: Intrameander hyporheic flow in alluvial rivers, Water Resour. Res., 44, W12428, doi:10.1029/2008WR007081, 2008.

Rivett, M., Buss, S., Morgan, P., Smith, J., and Bemment, C.: Nitrate attenuation in groundwater: A review of biogeochemical controlling processes, Water Res., 42, 4215-4232, doi:10.1016/j.watres.2008.07.020, 2008. 
Rodríguez, E.: Surface Water and Ocean Topography Mission (SWOT) Project - Science Requirements Document, JPL, https://swot.jpl.nasa.gov/files/swot/SWOT_Science_ Requirements_Document.pdf, last access: 10 August 2014.

Rosenberry, D. and Pitlick, J.: Local-scale variability of seepage and hydraulic conductivity in a shallow gravel-bed river, Hydrol. Process., 23, 3306-3318, doi:10.1002/hyp.7433, 2009.

Rosenberry, D., Sheibley, R., Cox, S., Simonds, F., and Naftz, D.: Temporal variability of exchange between groundwater and surface water based on high-frequency direct measurements of seepage at the sediment-water interface, Water Resour. Res., 49, 2975-2986, doi:10.1002/wrcr.20198, 2013.

Rossman, N. and Zlotnik, V.: Review: Regional groundwater flow modeling in heavily irrigated basins of selected states in the western United States, Hydrogeol. J., 21, 1173-1192, doi:10.1007/s10040-013-1010-3, 2013.

Rubin, Y., Lunt, I., and Bridge, J.: Spatial variability in river sediments and its link with river channel geometry, Water Resour. Res., 42, W06D16, doi:10.1029/2005WR004853, 2006.

Rühaak, W., Rath, V., Wolf, A., and Clauser, C.: 3D finite volume groundwater and heat transport modeling with non-orthogonal grids, using a coordinate transformation method, Adv. Water Resour., 31, 513-524, 2008.

Rushton, K.: Representation in regional models of saturated riveraquifer interaction for gaining/losing rivers, J. Hydrol., 334, 262281, doi:10.1016/j.jhydrol.2006.10.008, 2007.

Rushton, K. and Tomlinson, L.: Possible mechanisms for leakage between aquifers and rivers, J. Hydrol., 40, 49-65, 1979.

Russell, G. and Miller, J.: Global River Runoff Calculated from a Global Atmospheric General Circulation Model, J. Hydrol., 117, 241-254, 1990.

Ryan, R. and Boufadel, M.: Influence of streambed hydraulic conductivity on solute exchange with the hyporheic zone, Environ. Geol., 51, 203-210, doi:10.1007/s00254-006-0319-9, 2006.

Ryan, R. and Boufadel, M.: Evaluation of streambed hydraulic conductivity heterogeneity in an urban watershed, Stoch. Environ. Res. Ris. A., 21, 309-316, doi:10.1007/s00477-006-0066-1, 2007.

Saenger, N., Kitanidis, P., and Street, R.: A numerical study of surface-subsurface exchange processes at a riffle-pool pair in the Lahn River, Germany, Water Resour. Res., 41, W12424, doi:10.1029/2004WR003875, 2005.

Sahoo, A., Pan, M., Troy, T., Vinukollu, R., Sheffield, J., and Wood, E.: Reconciling the global terrestrial water budget using satellite remote sensing, Remote Sens. Environ., 115, 1850-1865, doi:10.1016/j.rse.2011.03.009, 2011.

Saleh, F., Flipo, N., Habets, F., Ducharne, A., Oudin, L., Viennot, P., and Ledoux, E.: Modeling the impact of in-stream water level fluctuations on stream-aquifer interactions at the regional scale, J. Hydrol., 400, 490-500, doi:10.1016/j.jhydrol.2011.02.001, 2011.

Saleh, F., Ducharne, A., Flipo, N., Oudin, L., and Ledoux, E.: Impact of river bed morphology on discharge and water levels simulated by a 1D Saint-Venant hydraulic model at regional scale, J. Hydrol., 476, 169-177, doi:10.1016/j.jhydrol.2011.02.001, 2013.
Salehin, M., Packman, A. I., and Paradis, M.: Hyporheic exchange with heterogeneous streambeds: Laboratory experiments and modeling, Water Resour. Res., 40, W11504, doi:10.1029/2003WR002567, 2004.

Sawyer, A. and Cardenas, M.: Hyporheic flow and residence time distributions in heterogeneous cross-bedded sediment, Water Resour. Res., 45, W08406, doi:10.1029/2008WR007632, 2009.

Schmidt, C., Bayer-Raich, M., and Schirmer, M.: Characterization of spatial heterogeneity of groundwater-stream water interactions using multiple depth streambed temperature measurements at the reach scale, Hydrol. Earth Syst. Sci., 10, 849-859, doi:10.5194/hess-10-849-2006, 2006.

Schmidt, C., Conant, B., Bayer-Raich, M., and Schirmer, M.: Evaluation and field-scale application of an analytical method to quantify groundwater discharge using mapped streambed temperatures, J. Hydrol., 347, 292-307, doi:10.1016/j.jhydrol.2007.08.022, 2007.

Schornberg, C., Schmidt, C., Kalbus, E., and Fleckenstein, J.: Simulating the effects of geologic heterogeneity and transient boundary conditions on streambed temperatures - Implications for temperature-based water flux calculations, Adv. Water Resour., 33, 1309-1319, doi:10.1016/j.advwatres.2010.04.007, 2010.

Schumm, S., A.: River response to baselevel change: Implications for sequence stratigraphy, J. Geol., 101, 279-294, doi:10.1086/648221, 1993.

Scibek, J., Allen, D., Cannon, A., and Whitfield, P.: Groundwatersurface water interaction under scenarios of climate change using a high-resolution transient groundwater model, J. Hydrol., 333, 165-181, doi:10.1016/j.jhydrol.2006.08.005, 2007.

Sebok, E., Duque, C., Engesgaard, P., and Boegh, E.: Spatial variability in streambed hydraulic conductivity of contrasting stream morphologies: channel bend and straight channel, Hydrol. Process., doi:10.1002/hyp.10170, in press, 2014.

Seitzinger, S., Styles, R., Boyer, E., Alexander, R., Billen, G., Howarth, R., Mayer, B., and Breemen, N. V.: Nitrogen retention in rivers: model development and application to watersheds in the northeastern u.s.a., Biogeochemistry, 57/58, 199-237, 2002.

Shope, C., Constantz, J., Cooper, C., Reeves, D., Pohll, G., and McKay, W.: Influence of a large fluvial island, streambed, and stream bank on surface water-groundwater fluxes and water table dynamics, Water Resour. Res., 48, W06512, doi:10.1029/2011WR011564, 2012.

Sophocleous, M.: Interactions between groundwater and surface water: the state of the science, Hydrogeol. J., 10, 52-67, doi:10.1007/s10040-002-0204-x, 2002.

Spanoudaki, K., Stamou, A., and Nanou-Giannarou, A.: Development and verification of a 3-D integrated surface water-groundwater model, J. Hydrol., 375, 410-427, doi:10.1016/j.jhydrol.2009.06.041, 2009.

Stallman, R.: Steady one-dimensional fluid flow in a semi-infinite porous medium with sinusoidal surface temperature, J. Geophys. Res., 70, 2821-2827, doi:10.1029/JZ070i012p02821, 1965.

Stanford, J. and Boulton, A.: Hydrology and the distribution of hyporheos: perspectives from a mesic river and a desert stream, J. N. Am. Benthol. Soc., 12, 79-83, 1993.

Stonedahl, S., Harvey, J., Wörman, A., Salehin, M., and Packman, A.: A multiscale model for integrating hyporheic exchange from ripples to meanders, Water Resour. Res., 46, W12539, doi:10.1029/2009WR008865, 2010. 
Stonedahl, S., Harvey, J., Detty, J., Aubeneau, A., and Packman, A.: Physical controls and predictability of stream hyporheic flow evaluated with a multiscale model, Water Resour. Res., 48, W10513, doi:10.1029/2011WR011582, 2012.

Storey, R. G., Howard, K., and Williams, D.: Factors controlling riffle-scale hyporheic exchange flows and their seasonal changes in a gaining stream: A three-dimensional groundwater flow model, Water Resour. Res., 39-2, 1034, doi:10.1029/2002WR001367, 2003.

Sulis, M., Meyerhoff, S., Paniconi, C., Maxwell, R., Putti, M., and Kollet, S.: A comparison of two physics-based numerical models for simulating surface water-groundwater interactions, Adv. Water Resour., 33, 456-467, doi:10.1016/j.advwatres.2010.01.010, 2010.

Swanson, T. and Cardenas, M.: Ex-Stream: A MATLAB program for calculating fluid flux through sediment-water interfaces based on steady and transient temperature profiles, Comput. Geosci., 37, 1664-1669, doi:10.1016/j.cageo.2010.12.001, 2011.

Tapley, B., Bettadpur, S., Ries, J., Thompson, P., and Watkins., M.: GRACE measurements of mass variability in the Earth system, Science, 305, 503-505, 2004.

Therrien, R., McLaren, R., Sudicky, E., and Panday, S.: HydroGeoSphere: A Three-Dimensionnal Numerical Model Describing Fully-integrated Subsurface and Surface Flow and Solute Transport, Tech. rep., Université Laval and University of Waterloo, 2010.

Thierion, C., Longuevergne, L., Habets, F., Ledoux, E., Ackerer, P., Majdalani, S., Leblois, E., Lecluse, S., Martin, E., Queguiner, S., and Viennot, P.: Assessing the water balance of the Upper Rhine Graben hydrosystem, J. Hydrol., 424-425, 68-83, doi:10.1016/j.jhydrol.2011.12.028, 2012.

Thouvenot-Korppoo, M., Billen, G., and Garnier, J.: Modelling benthic denitrification processes over a whole drainage network, J. Hydrol., 379, 239-250, doi:10.1016/j.jhydrol.2009.10.005, 2009.

Tonina, D. and Buffington, J. M.: Hyporheic exchange in gravel bed rivers with pool-riffe morphology: laboratory experiments and three-dimensional modelling, Water Resour. Res., 43, W01421, doi:10.1029/2005WR004328, 2007.

Tonina, D. and Buffington, J. M.: Effects of stream discharge, alluvial depth and bar amplitude on hyporheic flow in pool-riffle channels, Water Resour. Res., 47, W08508, doi:10.1029/2010WR009140, 2011.

Tóth, J.: A Theory of Groundwater Motion in Small Drainage Basins in Central Alberta, Canada, J. Geophys. Res., 67, 43754387, 1962.

Tóth, J.: A Theoretical Analysis of Groundwater Flow in Small Drainage Basins, J. Geophys. Res., 68, 4795-4812, 1963.

Trauth, N., Schmidt, C., Maier, U., Vieweg, M., and Fleckenstein, J.: Coupled 3-D stream flow and hyporheic flow model under varying stream and ambient groundwater flow conditions in a pool-riffle system, Water Resour. Res., 49, 1-17, doi:10.1002/wrcr.20442, 2013.

Turlan, T., Birgand, F., and Marmonier, P.: Comparative use of field and laboratory mesocosms for in-stream nitrate uptake measurement, Ann. Limnol. - Int. J. Limmol., 43, 41-51, doi:10.1051/limn:2007026, 2007.
Urquiza, J., N'Dri, D., Garon, A., and Delfour, M.: Coupling Stokes and Darcy equations, Appl. Numer. Math., 58, 525-538, doi:10.1016/j.apnum.2006.12.006, 2008.

van Balen, R., Kasse, C., and Moor, J. D.: Impact of groundwater flow on meandering; example from the Geul River, The Netherlands, Earth Surf. Proc. Land., 33, 2010-2028, doi:10.1002/esp.1651, 2008.

VanderKwaak, J. E. and Loague, K.: Hydrologic-response simulations for the R-5 catchment with a comprehensive physics-based model, Water Resour. Res., 37, 999-1013, 2001.

Vergnes, J.-P. and Decharme, B.: A simple groundwater scheme in the TRIP river routing model: global off-line evaluation against GRACE terrestrial water storage estimates and observed river discharges, Hydrol. Earth Syst. Sci., 16, 3889-3908, doi:10.5194/hess-16-3889-2012, 2012.

Vergnes, J.-P., Decharme, B., Alkama, R., Martin, E., Habets, F., and Douville, H.: A Simple Groundwater Scheme for Hydrological and Climate Applications: Description and Offline Evaluation over France, J. Hydometeorol., 13, 1149-1171, doi:10.1175/JHM-D-11-0149.1, 2012.

Vermeulen, P., te Stroet, C., and Heemink, A.: Limitations to upscaling of groundwater Flow models dominated by surface water interaction, Water Resour. Res., 42, W10406, doi:10.1029/2005WR004620, 2006.

Weill, S., Mouche, E., and Patin, J.: A generalized Richards equation for surface/subsurface flow modelling, J. Hydrol., 366, 9-20, 2009.

Weng, P., Sánchez-Pérez, J., Sauvage, S., Vervier, P., and Giraud, F.: Assessment of the quantitative and qualitative buffer function of an alluvial wetland: hydrological modelling of a large floodplain (Garonne River, France), Hydrol. Process., 17, 2375-2392, doi:10.1002/hyp.1248, 2003.

Werner, A., Gallagher, M., and Weeks, S.: Regional-scale, fully coupled modelling of stream-aquifer interaction in a tropical catchment, J. Hydrol., 328, 497-510, doi:10.1016/j.jhydrol.2005.12.034, 2006.

White, D. S.: Perspectives on Defining and Delineating Hyporheic Zones, J. N. Am. Benthol. Soc., 12, 61-69, 1993.

Whiting, P. and Pomeranets, M.: A numerical study of bank storage and its contribution to streamflow, J. Hydrol., 202, 121-136, 1997.

Winter, T.: Relation of streams, lakes, and wetlands to groundwater flow systems, Hydrogeol. J., 7, 28-45, 1998.

Woessner, W. W.: Stream and Fluvial Plain Ground Water Interactions: Rescaling Hydrogeologic Thought, Ground Water, 38, 423-429, doi:10.1111/j.1745-6584.2000.tb00228.x, 2000.

Wondzell, S. M. and Swanson, F. J.: Floods, channel change, and the hyporheic zone, Water Resour. Res., 35, 555-567, 1999.

Wondzell, S., LaNier, J., and Haggerty, R.: Evaluation of alternative groundwater flow models for simulating hyporheic exchange in a small mountain stream, J. Hydrol., 364, 142-151, doi:10.1016/j.jhydrol.2008.10.011, 2009.

Wood, E., Roundy, J., Troy, T., van Beek, L., Bierkens, M., Blyth, E., de Roo, A., Döll, P., Ek, M., Famiglietti, J., Gochis, D., van de Giesen, N., Houser, P., Jaffé, P., Kollet, S., Lehner, B., Lettenmaier, D., Peters-Lidard, C., Sivapalan, M., Sheffield, J., Wade, A., and Whitehead, P.: Hyperresolution global land surface modeling: Meeting a grand challenge for monitoring 
Earth's terrestrial water, Water Resour. Res., 47, W05301, doi:10.1029/2010WR010090, 2011.

Wroblicky, G., Campana, M., Valett, H., and Dahm, C.: Seasonal variation in surface-subsurface water exchange and lateral hyporheic area of two stream-aquifer systems, Water Resour. Res., 34-3, 317-328, doi:10.1029/97WR03285, 1998.

Yeh, P. and Eltahir, E.: Representation of Water Table Dynamics in a Land Surface Scheme. Part II: Subgrid Variability, J. Climate, 18, 1881-1901, 2005.

Yuan, D., Lin, B., and Falconer, R.: Simulating moving boundary using a linked groundwater and surface water flow model, J. Hydrol., 349, 524-535, doi:10.1016/j.jhydrol.2007.11.028, 2008.
Zaitchik, B., Rodell, M., and Reichle, R.: Assimilation of GRACE terrestrial water storage data into a land surface model: results for the Mississippi River Basin, J. Hydrometeorol., 9, 535-548, doi:10.1175/2007JHM951.1, 2008.

Zhou, Y. and Li, W.: A review of regional groundwater flow modeling, Geosci. Front., 2, 205-214, doi:10.1016/j.gsf.2011.03.003, 2011.

Zlotnik, V., Cardenas, M., and Toundykov, D.: Effects of Multiscale Anisotropy on Basin and Hyporheic Groundwater Flow, Ground Water, 49, 576-583, doi:10.1111/j.1745-6584.2010.00775.x, 2011. 